\title{
Advanced Metallic and Polymeric Coatings for Neural Interfacing: Structures, Properties and Tissue Responses
}

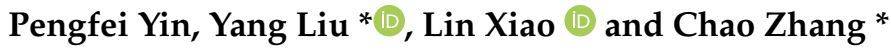 \\ Department of Biomedical Engineering, Sun Yat-sen University, Shenzhen 518107, China; \\ yinpf3@mail2.sysu.edu.cn (P.Y.); xiaolin23@mail.sysu.edu.cn (L.X.) \\ * Correspondence: liuyang56@mail.sysu.edu.cn (Y.L.); zhchao9@mail.sysu.edu.cn (C.Z.)
}

check for updates

Citation: Yin, P.; Liu, Y.; Xiao, L.; Zhang, C. Advanced Metallic and Polymeric Coatings for Neural Interfacing: Structures, Properties and Tissue Responses. Polymers 2021, 13, 2834. https://doi.org/10.3390/ polym 13162834

Academic Editor: Fuh-Yu Chang

Received: 27 July 2021

Accepted: 17 August 2021

Published: 23 August 2021

Publisher's Note: MDPI stays neutral with regard to jurisdictional claims in published maps and institutional affiliations.

Copyright: (c) 2021 by the authors. Licensee MDPI, Basel, Switzerland. This article is an open access article distributed under the terms and conditions of the Creative Commons Attribution (CC BY) license (https:/ / creativecommons.org/licenses/by/ $4.0 /)$.

\begin{abstract}
Neural electrodes are essential for nerve signal recording, neurostimulation, neuroprosthetics and neuroregeneration, which are critical for the advancement of brain science and the establishment of the next-generation brain-electronic interface, central nerve system therapeutics and artificial intelligence. However, the existing neural electrodes suffer from drawbacks such as foreign body responses, low sensitivity and limited functionalities. In order to overcome the drawbacks, efforts have been made to create new constructions and configurations of neural electrodes from soft materials, but it is also more practical and economic to improve the functionalities of the existing neural electrodes via surface coatings. In this article, recently reported surface coatings for neural electrodes are carefully categorized and analyzed. The coatings are classified into different categories based on their chemical compositions, i.e., metals, metal oxides, carbons, conducting polymers and hydrogels. The characteristic microstructures, electrochemical properties and fabrication methods of the coatings are comprehensively presented, and their structure-property correlations are discussed. Special focus is given to the biocompatibilities of the coatings, including their foreign-body response, cell affinity, and long-term stability during implantation. This review article can provide useful and sophisticated insights into the functional design, material selection and structural configuration for the next-generation multifunctional coatings of neural electrodes.
\end{abstract}

Keywords: neural interfacing; polymers; metals; coatings; electrodes; structure-property correlations; biocompatibility

\section{Introduction}

During the last few decades, neural electrodes have been considered as a promising interfacing technology for the direct probing and interfering of the neural tissues [1]. Neural interfaces have been employed to study the basic interactions of the brain-neural system, and to treat many neurophysiologic disorders, such as Parkinson's disease [2], deafness [3], blindness [4], epilepsy [5] and dyskinesia [6]. They can record a variety of physiologic signals from neural tissues and give stimulations to abnormal neurons to restore the neural system during their implantations. Many neural electrodes have been applied successfully for neural recording and stimulation [7-9]. However, several requirements must be met before the neural electrodes can be used in long-term implantation applications. First of all, the materials used to fabricate neural electrodes should be not only properly functioning in vivo but also biocompatible and durable in order to maintain the neural interface. Secondly, the electrical properties of neural electrodes should be engineered to the level suitable for distinct recording and stable stimulation, i.e., low impedance and a high charge injection limit. In order to minimize the damage applied to the brain tissues during implantation, the neural electrodes are generally fabricated into the form of microelectrodes. There are two typical types of microelectrodes, including microwires and micro-electromechanical system (MEMS) arrays. Different kinds of materials have been used to manufacture neural microelectrodes. Noble metals—such as gold [10], platinum [11] and tungsten [12]—are traditional choices for microwire-type microelectrodes. 
Magnesium, due to its biodegradable property, has also been studied for neural interfacing in order to avoid additional surgery after implantation $[13,14]$ (Figure 1a,b). Conducting materials other than metals-such as carbon nanotubes (CNT) [15], graphene [16] and conducting polymers [17] — have been recently utilized to fabricate MEMS arrays. The microelectrode-based MEMS arrays have been successfully applied in clinical neurophysiologic diagnosis and therapy for a few decades. Typical MEMS arrays include Utah arrays (Figure 1c) [18] and Michigan microelectrodes (Figure 1d) [19].

Noble metals possess excellent electrical conductivity, chemical stability and good biocompatibility, making them suitable for the fabrication of neural electrodes. However, there are certain limitations in metallic electrodes due to the mismatch between rigid metals and soft neural tissues regarding their electrical, mechanical and biological properties, making it hard to realize a metallic neural electrode with high sensitivity and spatial accuracy [20]; precise, tunable stimulation; and the least tissue response [21]. There are two different charge transport carriers in tissue and electrodes, i.e., ions for neural tissues and electrons for electrodes, resulting in electrical imparity [22]. The difference in the mechanical properties may cause a huge disparity in the Young's modulus between neural tissue ( $\mathrm{kPa}$ level) and the metallic electrode (GPa level). As the neural electrodes are implanted in brain neural tissues, it would induce damage to neurons and cause blood capillary fracture, resulting in the leakage of the blood-brain barrier and a tissue response [23]. Meanwhile, the implanted electrodes, while recognized as foreign body objects, will be attacked by the immune system, resulting in a series of inflammatory responses and the accumulation of microglia at the implant site, which may eventually cause the isolation of the electrodes from the tissue and the failure of the electrode [24]. The optimal design of an electrode with a conformal geometric size to reduce the implantation damage, the utilization of soft materials with a similar Young's modulus to the neural tissue are state-of-the-art concepts for the research and development of next-generation neural electrodes [25,26]. As the geometric size of metallic electrodes is reduced, their suitability for neural recordings may be significantly hindered due to their low charge injection capability and charge storage capacitance. A few soft organic polymers (PDMS (Figure 1e) [27,28], PI [29], parylene $\mathrm{C}$ [30], PU [31]) have been used to fabricate neural electrodes in order to mitigate the mechanical mismatch in the tissue-electrode interface. Compared to metals and carbon materials, polymeric materials are less efficient for the transfer of the electrical signals due to their low electrical conductivity [32]. The polymeric materials are also difficult to penetrate the body and fix in a specific implant site with due to their low Young's modulus. In order to prepare neural electrodes with both conformal characteristics and minimal geometric size, nanofabrication methods such as optical lithography have been introduced to fabricate sheet-shape MEMS arrays [33]. However, the intrinsic physical and chemical differences between the electrodes and neuronal tissues would induce an unstable electronic-tissue interface, which can be subsequently targeted and eliminated by the immune system; on the other, the conductive layer alone cannot facilitate advanced functions such as neuro-regeneration, molecular delivery and anti-inflammatory effects. In order to address these issues, functional coatings can be applied on the electrode surface in order to achieve the designated properties, biocompatibility and durability. The benefits of functional coatings may include, but are not limited to: (i) increasing the geometric surface area of the electrode; (ii) enhancing the electrochemical properties of the electrode; (iii) lowering the modulus of the electrode surface; (iv) reducing the foreign body response in the electrode-tissue interface; and (v) integrating advanced therapeutical functions into the electrode. Compared to the manipulation of the structure and composition of the electrode alone, surface coating is a relatively easy and cost-effective methodology to fabricate multiscale and multifunctional hybrid electrodes, while the coating materials and their microstructures can be selected and tuned in a user-specific manner. 
(a)

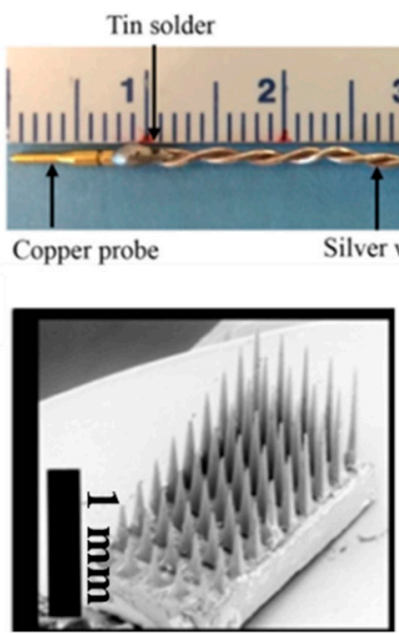

Copper tape PGS coating

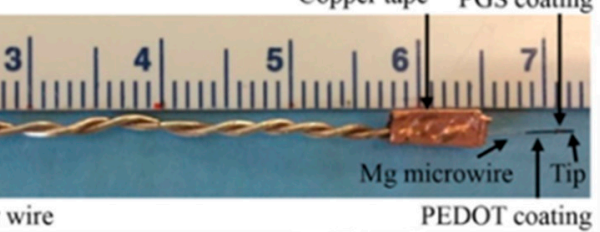

(b)
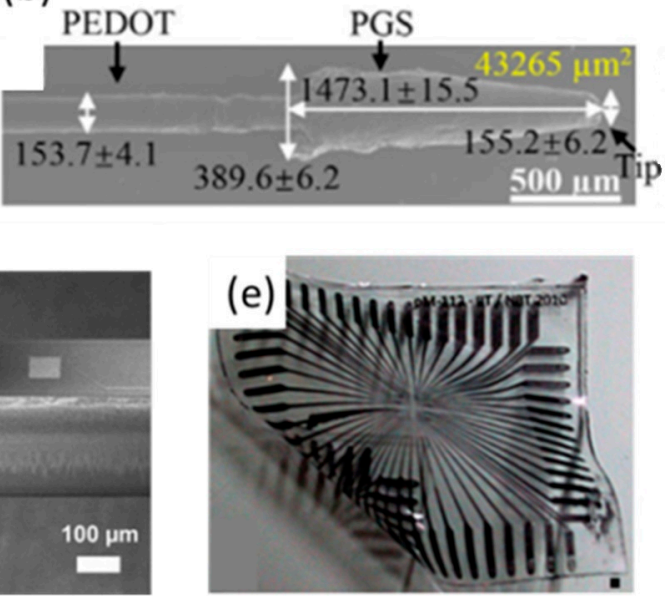

Figure 1. The macroscopic image (a) and morphology (b) of an Mg-based microwire electrode. An illustration of Utah-type (c), Michigan-type (d) and PDMS-based electrodes (e). (a,b) are reproduced with permission from [14], Copyright 2020, Elsevier. (c) is reproduced with permission from [18], Copyright 2014, iopscience.iop.org. (d) is reproduced with permission from [19], Copyright 2015, Elsevier. (e) is reproduced with permission from [27], Copyright 2011, Elsevier.

Thus, it is crucial to review the current situation of the neural electrode coatings and the recent developments in the coating procedures and technologies in the research field of neural interfacing. The coating on the electrode surface, which can serve as an interlayer between the neural electrodes and the target tissues, plays a significant role in the efficiency of the abiotic/biotic interface. For example, a coating layer with poor biocompatibility and electrical conductivity will significantly prevent the effectiveness of signal transduction in the interface. An interface with unsatisfactory chemical and mechanical properties may cause severe responses in the surrounding tissues, resulting in the failure of the neural device. Motivated by the above-mentioned issues, we undertake this review of coatings applied on the surface of neural electrodes, which highlights various successful works in this emerging field, and the existing challenges in the design of an ideal coating for a neural interface.

In the following sections, the mechanism of neural tissue responses to the implantable electrode in the electrode-tissue interface is discussed first. The materials used for the coating (e.g., metals and their derivatives, carbon materials, conducting polymeric materials, and hydrogel coatings) will be discussed in detail based on their electrical, mechanical and biological properties, and the corresponding fabrication methods. Correlations between the structure and properties of the coating also will be discussed. After all of this, perspectives on the challenges in the field and the future developments of the neural electrode coatings are depicted and demonstrated.

\section{Tissue Responses to Implantable Neural Electrodes}

When the electrodes are implanted in the central nervous system for a long period of time, they may trigger inflammatory responses [34,35]. The cells generated by the inflammatory response may include astrocytes, microglia and oligodendrocytes, etc. All of these cells can secrete inhibitory substances that impede the regeneration of axons. During the implantation of neural electrodes, the blood-brain barrier and blood vessels may be damaged, causing nerve cell death near the surface of the electrode. Then, the microglia and sources of activated macrophages in the blood may begin to migrate to the surface of the neural electrode and release cytokines, chemokines and neurotransmitters, such as oxygen free radicals for the cleaning of the dead neurons to constitute an acute inflammatory response [36]. The presence of implant trauma and an inflammatory response can result in tissue edema [34,37], which may cause the neurons around the electrode to move away from the electrode's surface. Moreover, as the blood-brain barrier is damaged, 
leukocyte infiltration, platelet aggregation and plasma exudation may jointly participate in the inflammatory response. After a week of implantation, microglia cells may clear a large amount of tissue debris through phagocytosis, and the tissue exudate absorption is also completed. Acute inflammatory response can be regarded as a process of repairing the tissue injury caused by the implantation process, and it would gradually subside after one or two weeks, which is a major cause of the malfunction and failure of the implanted electrodes.

After the acute response, the chronic inflammatory reaction phase begins, which features the presence of persistent inflammatory. In the chronic inflammatory reaction, the activated microglia may stick to the surface of the electrode, and the astrocytes are activated by the microglia, resulting in the formation of a glial scar around the electrode $[34,38]$. Microglia cell adhesion and aggregation on the electrode surface is the initial stage of chronic inflammatory response, and it takes place through the whole process of chronic inflammatory response. It has been found that the adhesion of microglia cells to the electrode surface was mediated by serum proteins [39]. In order to degrade and remove the foreign body (e.g., implanted electrodes), these activated microglia cells would secrete substantial decomposition enzymes and oxygen-free radicals, causing the death of the neurons around the electrode. In addition, the microglia may also secrete many cytokines, such as interleukin-1, interleukin- 6 and tumor necrosis factor $[40,41]$, which activate astrocytes. Astrocytes could also be activated by the source of the blood clotting enzyme, serum albumin and so on, which make the astrocytes proliferate and secrete an extracellular matrix, and inhibitory molecules, such as chondroitin sulfate proteoglycan [42]. Eventually, a dense layer of glial scar may form near the surface of the implanted electrode; this glial scar formation process generally takes about six weeks. As a result, the distance between the electrode and the target neuron increases, which further elevates the threshold value of the stimulation. Moreover, the formation of a glial scar around the electrode could inhibit the transmission of current and increase the impedance in the electrode-tissue interface. In order to achieve the optimal effect of the stimulation, the parameters for the electrical stimulation need to be adjusted, i.e., increasing the stimulating voltage, which further increases the energy consumption of the electrical stimulator, shortens the lifespan of the battery, and elevates the patient's burden [43]. More importantly, the death of the neurons around the electrode caused by the inflammatory response may induce the failure of the electrode. For example, a study by McConnell et al. found that neuronal degeneration mediated by local chronic inflammation was also a major causation for the connection failure between the electrodes and neurons [44]. In this study, it was observed that the signal recording performance of the neural electrodes degenerated after the glial scar was stabilized (about six weeks). However, this degenerative process may continue even after six weeks. After carefully examining and comparing the electrode implanted for 16 weeks with the 8-week sample, McConnell et al. found that macrophages around the electrode increased, and the expression of the Tau protein phosphorylated at Thr-231 loci was also detected, indicating neuron degeneration, and the immunoreactivity change of PT231. In the brain tissue of senile dementia patients, the same phenomenon was observed. It was thus indicated that the macrophages were in a state of continuous activation due to the continuous existence of the electrode. It was also found that an inflammatory response mediated a state of neurodegeneration around the electrode, and the progressive death of the neurons may lead to the decline or even failure of the recording function of the electrode after the stabilization of the glial scar [45-48].

\section{Metals and Their Derivatives}

Metals such as platinum, gold and silver have been successfully applied in the fabrication of neural electrodes due to their excellent electrical conductivity, biostability and resistance to corrosion [49]. Moreover, they are also used for the fabrication of microelectrodes with smaller geometric sizes [50]. However, surface modifications are generally required for metallic electrodes in order to engineer the biomechanical, electrochemical, 
and foreign body response in the electrode-neural interface. Metallic materials and their derivatives such as gold and iridium oxide with nanostructures are widely used to modify the surface of microelectrodes, because they can easily form intact coatings on gold and metal electrodes in order to avoid parasitic effects like bimetallic corrosion or delamination [51,52]. On the other hand, metals and their derivatives show higher mechanical strength than other materials, which is important for the chronic implantation of neural electrodes [53].

\subsection{Platinum Coatings}

Metallic materials and their derivatives are usually employed as coatings on the surface of the conductive sites of neural microelectrodes. Recently, nanoparticles and porous structures composed of metallic materials and their derivatives were utilized as the coating layer, which can remarkably increase the geometric surface area of the metallic electrode and bring a significant improvement to the electrochemical properties of the microelectrodes [54-58].

Platinum coatings formed by electrochemical deposition have gained much attention in neural electrodes. The rough platinum coatings with a high surface-to-volume ratio can effectively facilitate charge transfer and movement on neural electrodes. After the deposition of platinum coatings, the impendence of neural electrodes can be reduced at least four times [59-62], and the charge injection limitation of the neural electrode is increased by a factor of six $[59,60]$, which is beneficial to obtain high-quality signal recording and ensure a more efficient and safer charge delivery for stimulation. However, while the enhancement in the electrochemical performance of the neural electrode is well documented for platinum coatings, other crucial parameters such as biocompatibility, durability, mechanical stability and stimulation performance remain to be explored. Few studies have reported that platinum black coatings (Figure 2a) had poor mechanical durability, which greatly hindered their applications for long-term implantation [63,64]. In order to enhance the stability of platinum coatings on neural electrodes, many methods have been reported, such as ultrasonic agitation [64-66], adhesion promoter additives [67] and substrate roughening [68]. The ultrasonic agitation method is widely used to improve the stability of platinum coatings (Figure $2 \mathrm{~b}$ ), i.e., the ultrasonically treated platinum coating only lost $2.5 \%$ of itself after the stability test, while there was about $80 \%$ lost for the untreated platinum coatings [65]. Moreover, the ultrasonic platinum coating showed excellent chronic stability, and there was no evidence of severe damage to the electrochemical property or failure after several months of implantation. Other than the ultrasonic agitation method, Yu et al. presented a method to electroplate highly adhesive platinum black onto a microelectrode by using adhesion-promoter additives, which showed even better durability than those prepared by the ultrasonic agitation method [67]. According to their method, a fuzzy gold coating was first coated onto the electrode as the intermediate layer to enhance the adhesion of platinum coating on the microelectrode sites. As a comparison, both the ultrasonic-plated platinum black and the fuzzy gold interlayered platinum black coatings showed decreased the effective surface area and significantly increased the impedance. The fuzzy gold interlayered platinum black coatings maintained a larger effective surface area $(77 \%)$ than the ultrasonic plated platinum black. Although the platinum black coating formed by using traditional electroplating could enhance the neural electrode interface, the cytotoxicity of the platinum black is a serious concern. Few studies reported that the DNA synthesis of rat oligodendrocytes in vitro was inhibited when exposed to the platinum black extract [69]. The release of toxic lead, an ingredient of the conventional electroplating electrolyte, may be responsible for this issue [70]. Therefore, many new methods have been developed for the formation of the nanostructured platinum coating on the neural electrode interface. 
(a)

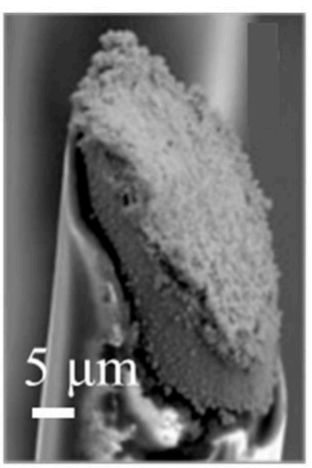

(d)
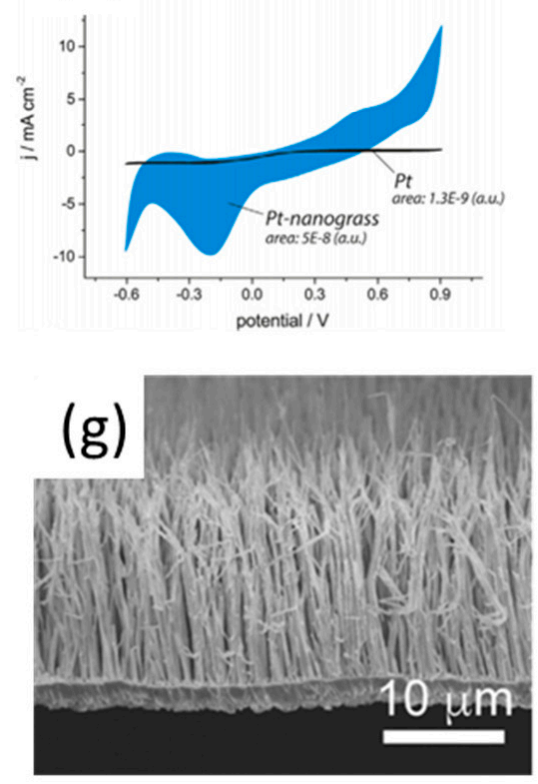
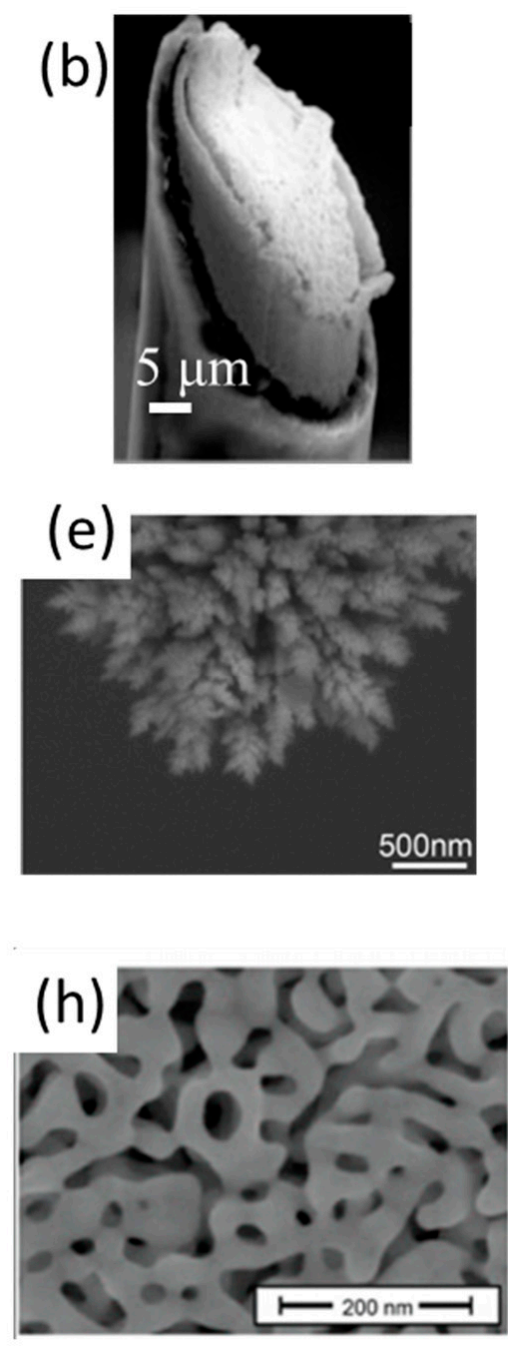

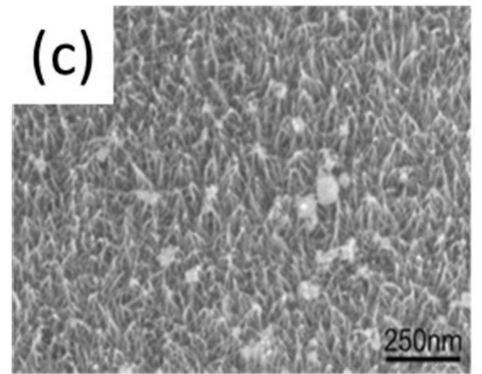

(f)
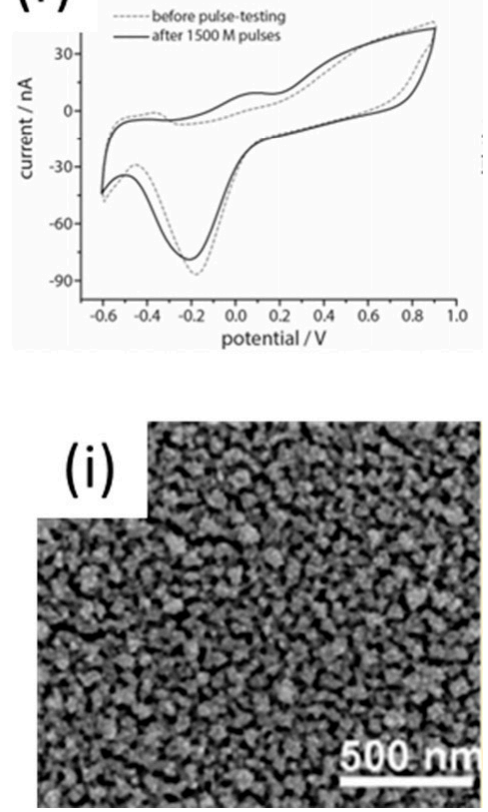

Figure 2. The SEM images of (a) the DC-plated platinum black, (b) the sonico-plated platinum black, (c) Pt-nanograss, (e) the NanoPt coating, (g) gold nanowires, (h) nanoporous gold, and (i) Au nanoparticles. (d) CV-measurements on 35-mm diameter electrode spots carrying the passive Pt-grass (blue squares) in comparison to sputtered Pt (black triangles). (f) The CV-characteristics show only marginal changes in response to the excessive pulsing $(n=5)$. $(\mathbf{a}, \mathbf{b})$ are reproduced with permission from [64], Copyright 2010, Frontiers. (c,d) are reproduced with permission from [71], Copyright 2015, Elsevier. $(\mathbf{e}, \mathbf{f})$ are reproduced with permission from [53], Copyright 2020, ACS Publications. (g) is reproduced with permission from [72], Copyright 2008, ACS Publications. (h) is reproduced with permission from [73], Copyright 2015, ACS Publications. (i) is reproduced with permission from [74], Copyright 2012, ACS Publications.

The three-dimensional nanostructured platinum coating can be fabricated by chemical or electrochemical depositions, which do not contain cytotoxic components like lead. There were no toxic effects of the extract products of the coatings fabricated by these two methods on cells during in vitro experiments [71]. Chemical deposition can endow the platinum coatings with nanowire-like structures and a higher effective surface area, while electrochemical deposition could form clear specific patterns of coatings efficiently. Boehler et al. introduced a chemical deposition method for the formation of nanostructure platinum grass to enhance the neural electrode interface [71]. Because of the high effective surface area of the platinum nanograss (Figure 2c), the electrochemical property of the coating was significantly improved (Figure $2 \mathrm{~d}$ ), with a significant decrease of the impedance of almost two orders of magnitude, and a dramatic increase in the charge delivery capacity. The nanograss coating was non-toxic, as confirmed by an elution testing spanning over the different concentration levels. Although the effective surface area can be increased, coatings formed by a chemical reduction process were highly time-dependent and hard to control 
due to the limitations of the chemically reducing agent, which prevented the fabrication of application-specific coating morphologies and substantially limited the reproducibility and the mass production of the coated electrodes. A new electrochemical deposition method without the chemically reducing agent for the formation of a nanostructure platinum (nanoPt) coating (Figure 2e) may be possible in order to substantially improve the process control that is vital for large-scale fabrication [53]. The morphology of the electrochemically deposited nanoPt coatings could be selectively modified by dynamically varying the deposition voltage during the electrochemical reduction process. The nanoPt coating can maintain its stability over more than 1 billion stimulation pulses under a charge density of $1.5 \mathrm{mC} \mathrm{cm}^{-2}$ (Figure 2f).

\subsection{Gold Coatings}

In addition to platinum, gold $(\mathrm{Au})$ with micro-/nano-structures is also used as a coating for neural microelectrodes. Gold coatings could be fabricated by many methods, such as chemical reduction [75], evaporation [76] and sputtering [77]. In order to enhance the electrochemical property of the neural microelectrodes, templates with nanoscale structures were used to increase the effective surface of gold coatings [72,75,78]. Nakanishi et al. used the anodic aluminum oxide template to fabricate gold nanowires through an electrodeposition technique [72]. The vertically aligned structure of the nanowires was observed by SEM (Figure $2 \mathrm{~g}$ ). Tybrandt et al. employed titanium dioxide nanowires as a starting material to fabricate gold-coated titanium dioxide nanowire $\left(\mathrm{Au}-\mathrm{TiO}_{2} \mathrm{NWs}\right)$ coatings for neural microelectrodes. The electrode coated with $\mathrm{Au}-\mathrm{TiO}_{2} \mathrm{NWs}$ had a high areal capacitance, with $2.7 \mathrm{mC} \mathrm{cm}^{-2}$, and it also showed stable neural recording after implantation for 3 months [75]. Dealloying was used to form a gold coating with a higher porosity and interconnectivity [73,79-81]. In a typical process, an Ag-Au alloy coating was first co-deposited on the electrode; subsequently, Ag was selectively dissolved to form the nanoporous gold coating (Figure $2 \mathrm{~h}$ ). The impedance of the nanoporous gold coated electrode was decreased by more than 25 times, and the biocompatibility of these coatings was also good [73]. The direct deposition of gold nanoparticles and substrate roughening were also utilized to improve the effective surface area of the gold coating [74,76]. The layer-by-layer (LBL) assembly of the Au nanoparticles (NP) (Figure 2i) achieved superior improvements on the electrical conductivity and charge transfer properties of the electrode as compared to CNT coatings. The good adherence, viability and differentiation of cultured neurons indicated that the LBL Au coating was also biocompatible [74]. Moreover, in order to achieve the high-density adhesion of neural cells to the neural microelectrode conductive sites, Mescola et al. proposed a two-step functionalization method to endow the neural cells with selective-adhesion ability to the gold surface, which provided an effective way to construct a stable electrode-nerve interface between neural cells and gold microelectrodes [82].

\subsection{Iridium Oxide}

Due to platinum and gold's faradaic nature, their limitations of charge delivery capacity remain a great challenge, especially for the electrodes with small geometric surface areas. With weak or no faradaic reaction charge transduction, the contribution of doublelayer capacitive coupling in charge delivery is often limited [83]. Thus, materials with higher electroactivity and ability to support reversible faradaic reactions are needed to promote the charge transfer in the electrode-tissue interface. Iridium oxide $\left(\mathrm{IrO}_{\mathrm{x}}\right)$ is a good candidate material for neural electrode coatings due to its low impedance, high charge storage capacity and charge injection capacity $[55,84-87]$. $\mathrm{IrO}_{\mathrm{x}}$ also shows good biocompatibility and high corrosion resistance $[56,88]$. The neural microelectrode coated with $\mathrm{IrO}_{\mathbf{x}}$ displayed an excellent stimulating function for individual neurons and recorded multiple single-unit spike activity with good signal-to-noise ratios $[89,90]$. The structure and properties of $\mathrm{IrO}_{x}$ are different based on the fabrication methods [91]. There are many kinds of iridium oxide, including sputtered iridium oxide film (SIROF) (Figure 3a) $[85,87,91-94]$, 
electrodeposited iridium oxide film (EIROF) (Figure 3b) [84,95-98], activated iridium oxide film (AIROF) (Figure 3c) [86,99-102], atomic-layer-deposited iridium oxide film [103], and physical-vapor-deposited iridium oxide film [104]. A porous iridium oxide layer could be observed for AIROF and EIROF, while SIROF showed a dendritic surface structure. AIROF and EIROF showed a higher charge storage capacity and lower impedance than SIROF for similar thicknesses, because AIROF and EIROF had a more open and porous structure, but SIROF exhibited better performance in terms of electrochemical and mechanical stabilities than AIROF. SIROF was more durable than AIROF under continuous high-charge-density stimulations, and SIROF was also found to keep its electrochemical property in ambient conditions which lasted for a month. In order to enhance the electrochemical performance of $\mathrm{IrO}_{x}$ coatings, electrochemical activation was employed to endow the $\mathrm{IrO}_{x}$ coatings with higher porosity and a larger effective surface area.
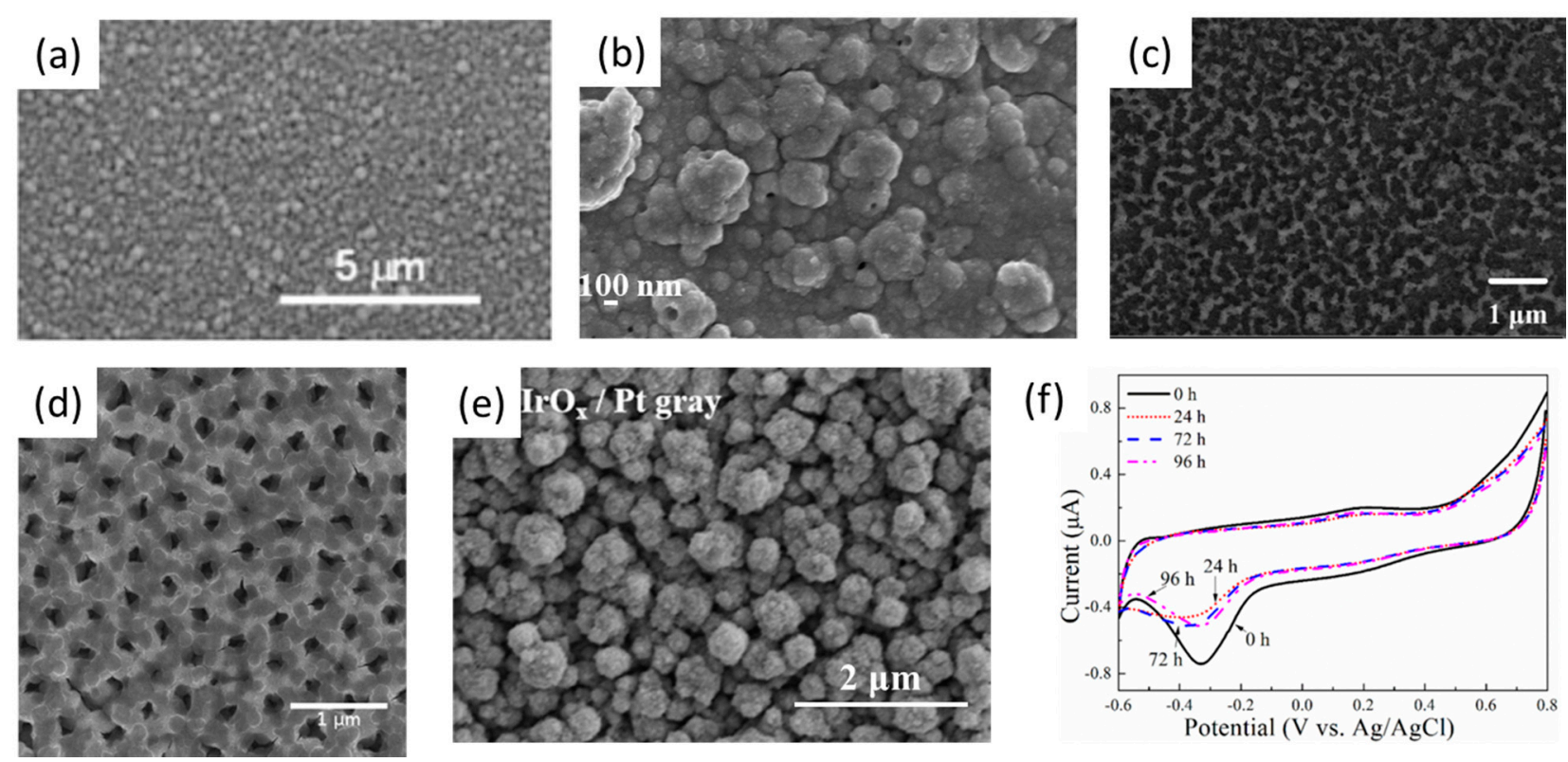

Figure 3. SEM image of (a) SIROF, (b) EIROF, (c) AIROF, (d) nanoporous AIROFs, and (e) $\mathrm{IrO}_{\mathrm{x}} / \mathrm{Pt}$ gray. (f) Cyclic voltammograms of an $\mathrm{IrO}_{\mathrm{x}} / \mathrm{Pt}$ gray-coated microelectrode before and after $24 \mathrm{~h}, 72 \mathrm{~h}$ and $96 \mathrm{~h}$ of continuous stimulations. (a) is reproduced with permission from [85], Copyright 2009, Wiley Online Library. (b) is reproduced with permission from [97], Copyright 2009, Elsevier. (c) is reproduced with permission from [107], Copyright 2014, Elsevier. (d) is reproduced with permission from [105], Copyright 2010, Elsevier. (e,f) are reproduced with permission from [106], Copyright 2017, Elsevier.

However, it is contradictory that the electrochemically activated iridium oxide coating obtained better electrochemical performance at the expense of its mechanical properties, which are important for the chronic implantation of a neural microelectrode. Other metals and metallic oxides were also used as templates or additives to improve the functions of the $\mathrm{IrO}_{\mathrm{x}}$ coating [78]. David et al. utilized a nanoporous anodized aluminum oxide (AAO) template to produce AIROF [105], which possessed a high charge storage capacity of more than $300 \mathrm{mC} \mathrm{cm}^{-2}$ and good mechanical stability (Figure 3d). The impedance of the gold nanowires modified with an EIROF coating was found to decrease by about three orders of magnitude, and the modified neural electrode had a good performance in recording neural spikes in vivo [78]. Zeng et al. combined iridium oxide with platinum gray to fabricate EIPOF/Pt gray composite coatings [106]. Due to the large surface area of the nanoconeshaped Pt gray (Figure 3e), iridium oxide could firmly adhere to the microelectrode, which showed superior mechanical and electrochemical stability (Figure 3f). An ultrasound bath was employed to test the mechanical stability of the EIPOF/Pt gray coating. The impedance 
of the EIPOF/Pt gray coating was stable at $3.5 \mathrm{k} \Omega$ after ultrasonic treatment $(50 \mathrm{~W})$ for $1 \mathrm{~h}$, which was about 15 times lower than bare Pt.

\section{Carbon Materials}

Although nanostructured metals and their derivatives could be used to construct the coating layers of neural electrodes, which can increase the effective surface area and improve the electrochemical properties of the neural interface, the stability issues of metallic coatings in vivo have raised serious concerns. For example, platinum black with a porous, low-impedance structure is mechanically fragile and degradable in the physiological environment [108]. An activated $\mathrm{IrO}_{x}$ coating with excellent charge transfer properties was used for neural stimulation, but the surface of it was found to be chemically unstable [109]. Carbon materials, such as carbon nanotubes (CNT) and graphene, are recognized as promising candidates to compromise the disadvantages of the metallic coatings, due to their lower toxicity, larger surface area, excellent electrical properties, and biocompatibility [110-114]. CNTs and graphene have been confirmed to be promising coatings for neural electrodes by numerous studies, as described in the following sections.

\subsection{Carbon Nanotubes}

Carbon nanotubes are composed of rolled-up graphene sheets, which can be classified into two types based on their wall structure, i.e., single-wall carbon nanotubes (SWCNTs) and multi-wall carbon nanotubes (MWCNTs) [115]. Due to their large surface area, and good electrical and physical properties, such as high conductivity and a high aspect ratio [116], carbon nanotubes are used as superior coating materials for neural microelectrodes, which have shown low impedance, high charge transfer mobility, chemical stability, and biocompatibility. The reported impedance values of neural electrodes coated with CNTs are lowered by 10 to 60 times compared to those of the bare electrode $[52,112,117,118]$. In addition, due to the high surface-to-volume ratio of CNTs, the charge storage capacity (CSC) of the CNT-coated neural electrode can be increased by about 3-140 times, which is higher than PEDOT and $\mathrm{IrO}_{x}$ with the same thickness $[119,120]$. Because of the excellent mechanical strength and ductility of CNTs, CNT films could strongly adhere to the surfaces of microelectrodes [121,122]. Moreover, CNT-coated electrodes showed good stability in mechanical and electrochemical tests. For example, after hundreds of cyclic voltammetry (CV) tests, the CNT-coated electrode exhibited a minimal loss of electrochemical properties compared to the conducting polymer coatings, and kept its structure intact when the PEDOT coatings broke and formed cracks [123].

CNT coatings can be deposited on the conductive sites of the neural electrodes by a variety of methods, including chemical vapor deposition (CVD) [124-128], electrochemical deposition (ED) [129], microwave plasma [130], layer-by-layer assembly (LBL) [131-133], solvent evaporation [134], and covalent attachment [119]. The physical, chemical and bio-properties of the CNT coatings can be determined by the fabrication methods. CVD is one of the most widely used methods to produce CNTs. CNTs synthesized by CVD can be grown to highly porous mats or highly ordered and vertically aligned pillar bundles by applying different lithographic patterns of catalyst [128]. The highly porous CNTs with a fluffy mat structure have a larger surface area for charge transfer and the preferential adhesion of neural cells via dendrite entanglement to the carbon nanotubes, which can significantly improve the signal recording of the neural electrode [118]. The CNT pillar coating generated by CVD also exhibited excellent mechanical stability and electrochemical properties. Nguyen-Vu et al. fabricated vertically aligned carbon nanofiber arrays (Figure 4a) to improve the performance of neural microelectrodes through the construction of a three-dimension interface between the microelectrodes and local neural tissues [135]. The as-prepared CNT array was a unique, highly porous 3D material with a large surface area. When bent by the cell bodies, the breakage and delamination of the CNTs from the electrode sites during the in vitro tests were not observed, indicating the superior flexibility and strength of the highly order and vertically aligned carbon nanotube pillar 
bundle coatings. The structure of the aligned CNTs was similar to the highly oriented pyrolytic graphite, and thus the aligned CNTs were shown to have faster electron transfer kinetics than the randomly oriented CNTs [136]. However, the randomly oriented CNTs may exhibit a better electrochemical property than aligned CNTs because of their enhanced porosity. The aligned CNT-coated electrodes had extremely low impedances and provided a roughened surface that produced excellent cell-electrode coupling [137]. However, the deposition of CNTs by CVD requires a high temperature $\left(400-900{ }^{\circ} \mathrm{C}\right)$, which is only applicable to thermally stable electrode and substrate materials.

Compared to CVD, electrochemical deposition has several advantages because the coating process is simple and could be completed in ambient conditions and a mild solution. The structures and properties of CNT coatings obtained by electrochemical deposition can be controlled by parameters such as the CNT concentrations, deposition charges and choice of electrolytes. The CNT coatings fabricated by electrochemical deposition are porous but fragile, which would limit their electrochemical performance during long-term implantation [138]. Moreover, this problem also occurs in CNT coatings made by simple solvent evaporation due to the planar morphology of the coating [134]. In order to enhance the stability of the CNT coating on a neural electrode, covalent attachment is a preferable choice. The coherent and stable CNT coatings can adhere to the electrode sites through covalent bonds. The study by Keefer et al. showed that the parylene insulation was peeled back from the electrode and rolled up to the shaft by the mechanical stress while the covalently attached CNTs remained intact during the implantation (Figure 4b) [119]. Implantable neural microelectrodes require superior mechanical properties in order to withstand chronic stresses and harsh physiological conditions. Furthermore, the layerby-layer (LBL) assembly technique is also applied to fabricate multilayered composites of CNTs and polyelectrolytes, which is attractive for the construction of a robust neural interface. The surface morphology of the CNT coatings obtained by LBL is composed of uniformly dispersed CNT bundles with nanoscale roughness, which can significantly increase the surface area, improve the charge transfer efficiency, and provide superior structural stability. The thickness of the LBL CNT coatings can be controlled with precision by the number of layers of CNTs and polyelectrolytes, respectively. Jan et al. reported that the LBL MWCNT coating showed better performance than PEDOT and $\mathrm{IrO}_{x}$ films in terms of impedance, charge storage capacity and charge transfer efficiency. The uniform coating made by LBL assembly could transfer both ions and electrons, and no signs of failure of the charge storage capacity was detected after $300 \mathrm{CV}$ cycles, showing that the coating was highly stable under the in vitro electrochemical conditions (Figure 4c,e,g) [117].

Although the CNT coatings have shown significant capabilities in improving the functions of neural electrodes, the toxicity issues are essential. Few studies reported that the aggregation of CNTs in the surrounding tissues may cause severe tissue damage $[139,140]$. CNTs modified with natural or synthetic biocompatible polymers could overcome such problems. Cho et al. prepared a series of electrically conductive CNT/collagen composites to study their cellular responses when PC12 cells were grown on this composite film with or without electrical stimulation [141]. The results indicated that as the content of collagen increased, PC12 cells showed enhanced attachment on the CNT/collagen composite due to the ability of collagen to improve the adhesion and viability of the nerve cells. The CNTs in the hyaluronic acid (HA) nanofiber composites proposed by Steel et al. were proven to enhance and accelerate the regenerative behaviors of the neurons under safe and effective electrical stimulations [142]. The CNT coatings encapsulated by biocompatible borondoped diamond were shown to promote the growth of cells and reduce the unfavorable release of CNTs into the surrounding tissues [143]. The surface of the CNT coatings functionalized by amino groups were also proven to support the adhesion and growth of neuronal cells in vitro [144]. Moreover, CNT coatings functionalized with other molecules, such as nucleic acids, drugs and proteins, have been used as controllable drug release systems. For example, Cui's group used MWCNTs as nano-reservoirs for drug delivery (Figure 4d) [145]. To speak further, the inner cavity of MWCNTs can be filled with a 
dexamethasone solution and encapsulated in polypyrrole (PPy) thin films. Compared to the conventional PPy thin film, the MWCNT coating displayed a higher drug loading capacity and a more linear and continuous release profile under electrical stimulations (Figure 4f) [145].

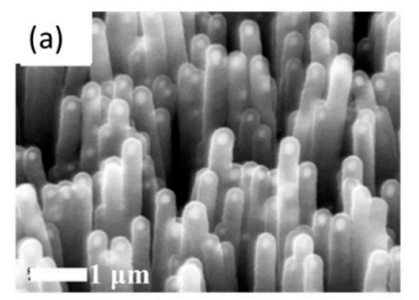

(d)

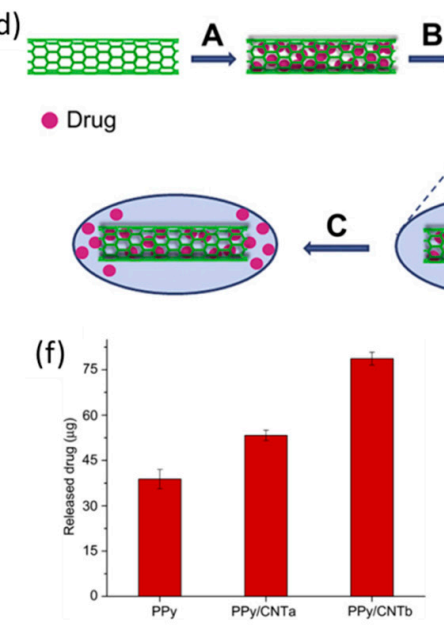

(b)

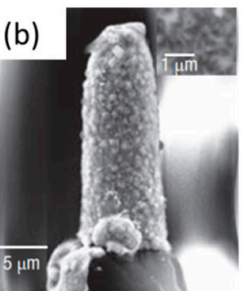

$\stackrel{\text { B }}{\longrightarrow}$

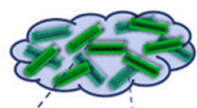

(c)

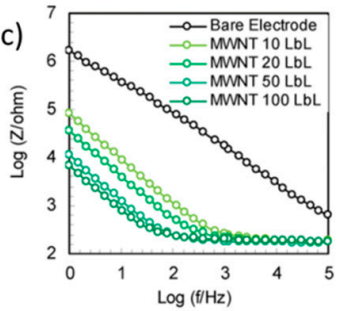

(1)

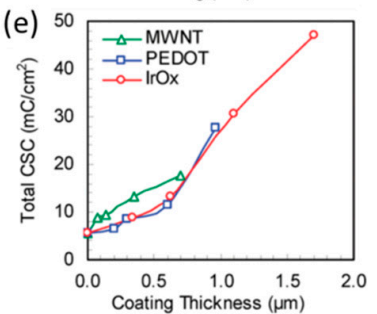

Figure 4. SEM images of (a) an as-grown carbon nanofiber array and (b) CNT coating by covalent attachment. (a) is reproduced with permission from [135], Copyright 2006, Wiley Online Library. (b) is reproduced with permission from [119], Copyright 2008, nature.com. (c) EIS of CNT coatings with different thicknesses. (d) Schematic of the drug loading and release process of CNT nano-reservoirs. (e) The total CSC of CNTs, PEDOT and $\mathrm{IrO}_{x}$ coatings. (f) Dex released from different PPy films under electric stimulation for $20 \mathrm{~h}$. The electric stimulation applied was a $50 \%$ duty cycle of square wave, $2 \mathrm{~V}$ for $5 \mathrm{~s}$ followed by $0 \mathrm{~V}$ for $5 \mathrm{~s}$. The data are shown \pm the standard deviation $(n=3$ for each case). (g) The total charge storage capacities (CSC) of the CNTS, PEDOT and $\mathrm{IrO}_{x}$ coated electrodes were recorded while being subjected to 300 cyclic voltammetry scanning cycles. (c,e,g) are reproduced with permission from [117], Copyright 2009, ACS. (d,f) are reproduced with permission from [145], Copyright 2011, Elsevier.

\subsection{Graphene}

Graphene has recently become an attractive candidate for neural interfacing owing to its superior chemical and physical properties, including its high conductivity, good chemical stability, flexibility, transparency and biocompatibility. In recent years, the studies of neuron networks cultured on graphene-based neural electrode coatings have shown that graphene was compatible to neural cells [146-148]. The fabrication methods of graphene coatings on neural electrodes include graphite exfoliation [149-151], electrochemical exfoliation [152-154] and CVD growth [155-157]. Due to the unique 2D structural features associated with its large specific surface area and superior electrical conductivity, the graphene coating can remarkably improve the electrochemical properties of neural electrodes. However, the charge storage capacity of graphene was limited due to its flat surface. Increasing the surface roughness of the graphene coating is an effective approach to improve the efficiency of the micro-stimulations delivered by the neural microelectrodes. A 3D porous graphene coating (Figure $5 \mathrm{a}$ ) was produced by Lu et al. though the direct laser pyrolysis method [158]. The electrode-coated porous graphene exhibited a high charge 
injection capacity (CIC) of $3 \mathrm{mC} \mathrm{cm}-2$ and an impedance lower than a gold electrode with similar sizes (Figure $5 b, c$ ). The in vivo test results showed that high density porous graphene electrode arrays could deliver electrical micro-stimulations to map cortical areas with both high resolution and high precision (Figure 5g). Due to its transparency, neural electrodes based on a graphene layer have been applied for simultaneous electrophysiology and neuroimaging [159]. Graphene-coated copper microwires that are highly compatible with magnetic resonance imaging (MRI) can be applied in the recording of brain activities and clinical diagnoses [21].

The in vitro studies showed that graphene could support the growth of neural cells and regenerate the targeted, damaged neurons, rather than inducing the proliferation of reactive astrocytes which could reduce the lifetime of the implanted electrodes [160-164]. Bendali et al. cultured purified adult (8-week old) retinal ganglion cells (RGC) on bare graphene in order to study the growth process of neurons directly in contact with graphene. The results indicated that neurons with outgrown neurites could easily survive on the nonpeptide-coated graphene, showing the high cytocompatibility of graphene. Additionally, the graphene substrates were reported to promote the neurite sprouting and outgrowth of mouse hippocampal cells after 7 days of culture (Figure 5d,e) by Li et al. [148]. Furthermore, few studies focused on the tissue response to graphene coatings in vivo and the correlative effects on the detection efficiency and time reliability of neural electrodes [165-167]. The work from Bourrier et al. indicated that the proliferations of astrocytes and microglia were significantly reduced around the monolayer graphene-coated probes after 5 weeks of implantation, suggesting that graphene was associated with the reduction of the tissue response due to its flexibility and function as a diffusion barrier [168]. Moreover, graphene was also able to enhance the neuronal differentiation of human neural stem cells (hNSCs). The hNSCs exhibited excellent adhesion on graphene during the long-term differentiation process, and the differentiation of hNSCs may progress toward neurons rather than glial cells on graphene (Figure 5f) [169].

(a)

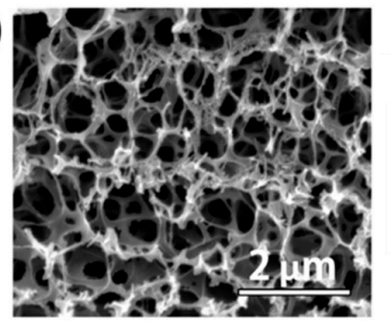

(d)

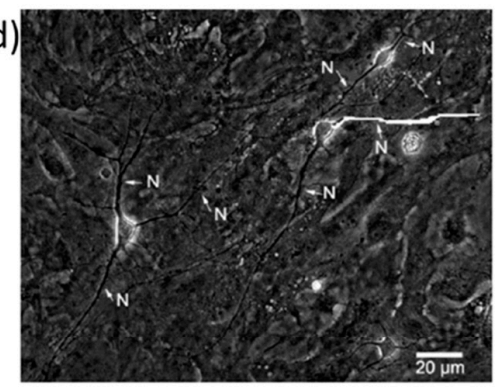

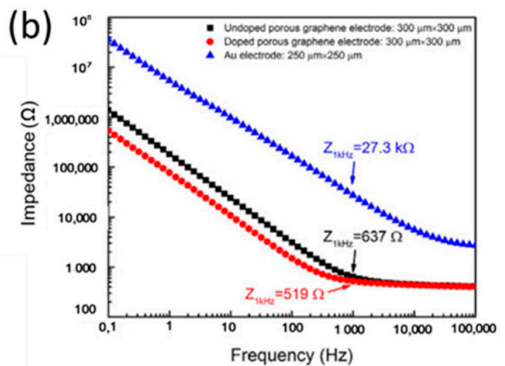

(e)

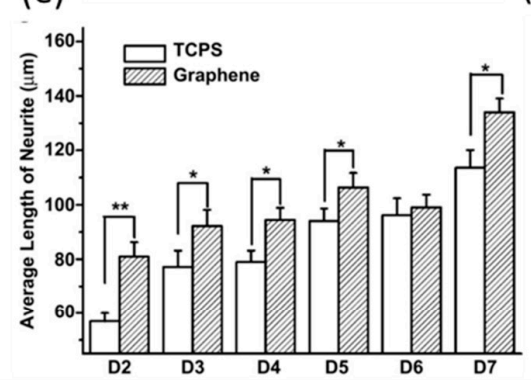

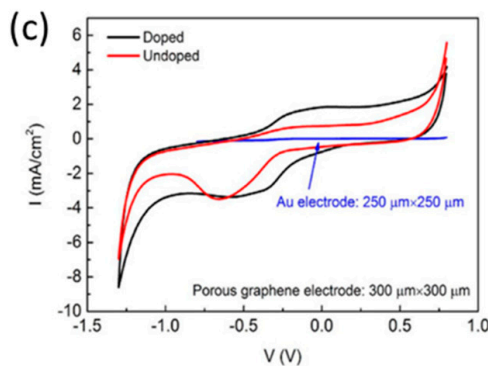

(f)

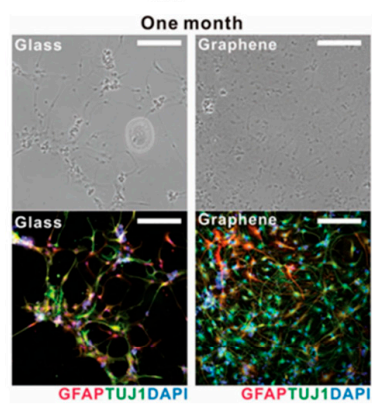

(g)

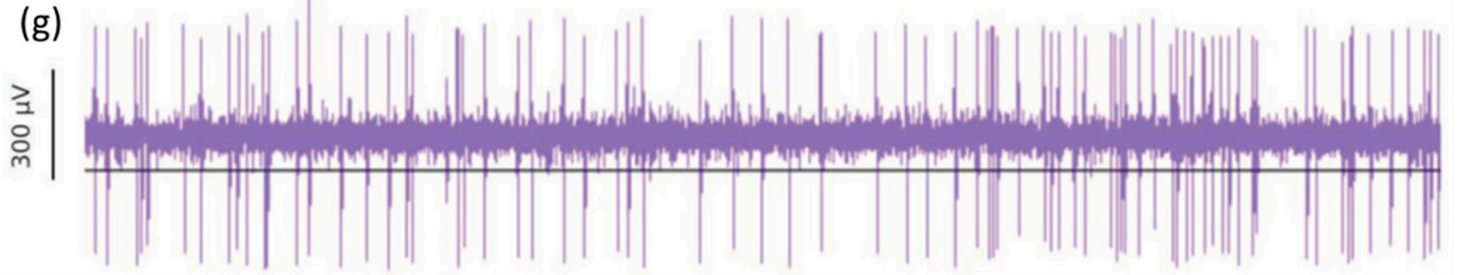

Figure 5. (a) SEM image of the 3D porous graphene. (b) EIS of a comparison of doped and undoped porous graphene 
and Au electrodes. (c) CV-characterization of porous graphene and Au electrodes. $(\mathbf{a}-\mathbf{c})$ are reproduced with permission from [158], Copyright 2016, Springer Nature. (d) Phase-contrast micrograph of typical neurons showing a trace along the extension of neurite $(\mathrm{N})$ used for length calculation, $(\mathbf{e})$ average number of neurites per neuron on TCPS and graphene during the developing period (D2-D7). (d,e) are reproduced with permission from [148], Copyright 2011, Elsevier. (f) Bright-field (top row) and fluorescence (bottom row) images of hNSCs differentiated on glass (left) and graphene (right) after one month of differentiation. The differentiated hNSCs were immune-stained with GFAP (red) for astroglial cells, TUJ1 (green) for neural cells, and DAPI (blue) for nuclei. Note that more hNSCs were adhered to graphene than to glass. All scale bars represent $200 \mu \mathrm{m}$. (f) is reproduced with permission from [169], Copyright 2011, Wiley. (g) Representative voltage time trace of graphene-coated NeuroNexus probe. (g) is reproduced with permission from [168], Copyright 2019, Wiley.

\section{Conducting Polymers}

Due to their versatile chemical structures and tunable surface functionalities, polymers have been utilized as advanced materials for biomedical engineering. Among the synthetic polymers, conducting polymers (CPs) are electroactive and nontoxic, and have received considerable attention as promising coatings for neural interfacing [170,171].

CPs originated from the discovery of polyacetylene in the late 1970s [172]. Subsequently, the discovery and development of CPs won the Nobel Prize in chemistry in 2000 [173-175]. The alternate single- and double-bond conjugating backbones form the molecular structure of CPs, facilitating electronic conductivity after doping with electron donor or acceptor dopants [176]. Because of their low elastic modulus, good biocompatibility and excellent conductive properties, CPs have been employed in a wide range of energy storage and biomedical applications, such as supercapacitors $[177,178]$, biosensors [179,180], tissue engineering [181,182] and drug delivery systems [183,184]. Recently, many studies have focused on the applications of CPs in neural interfacing [185-190].

CPs-such as polypyrrole (PPy), polyaniline (PANI), poly(3,4-ethylenedioxy thiophene) (PEDOT) and their derivatives-have been widely used in biomedical applications. Among CPs, PPy and PEDOT have received more interest in neural interfaces due to their biocompatibility, high electron and ion conductivity, and ease of coating. The synthesis of CPs can be accomplished by solution precipitation and electrochemical polymerization [17,191-193]. Generally speaking, the yield of CPs synthesized by solution precipitation is higher than that of electrochemical polymerization, but it is hard to directly apply a homogeneous CP coating onto a metallic substrate through solution precipitation [191]. The electrochemical deposition of CPs is widely used to fabricate well-defined CP thin films on the electrode surface, as the thickness, surface structure and electrical conductivity of the CP film can be readily controlled by adjusting the electrochemical parameters $[17,191,192]$.

Electrodes coated with CPs have shown superior electrochemical properties, such as lower impedance, higher CSC, a higher charge injection limit (CIL), and better biocompatibility than uncoated electrodes. Cui et al. modified the conductive sites of neural electrodes by the electrochemical deposition of PPy doped with polystyrene sulfonate (PSS) [17]. The results indicated that the impedance of the PPy/PSS-coated electrode was 30 times lower than a bare gold electrode at the biologically related frequency of $1 \mathrm{kHz}$, which can be attributed to the enhanced electrochemically active surface area created by the PPy coating. A study by Venkatraman et al. indicated that a PEDOT-coated electrode showed a CIL 15times higher than the same $\mathrm{IrO}_{x}$ coating at zero voltage bias [192]. The CP-coated electrode also exhibited remarkable performance in neural signal recording and stimulation in vivo. Martin's group found that the SNR $(5.1 \pm 1.2)$ of the signals recorded on PEDOT-coated neural probes was significantly higher than the SNR $(4.3 \pm 1.0)$ of the signals recorded on uncoated electrode sites after 15 days of implantation (Figure 6a,b) [192]. Furthermore, other in vivo studies also showed similar results, i.e., that the CP-coated electrodes can significantly increase the SNR and the population of neural cells recorded [193].

For electrochemically polymerized CP films, the types of dopants may have a significant impact on their structural, chemical and physical properties. Many dopants have been used in the literature, such as sodium chloride $(\mathrm{NaCl})$ [32], lithium perchlorate $\left(\mathrm{LiClO}_{4}\right)$ [194], sodium benzenesulfonate (BS) [194], sodium p-toluenesulfonate (pTS) [195], tetrabutylammonium 
perchlorate (TBAP) [196], sodium dodecylbenzene sulfonate (DBS) [197], heparin [198] and poly(sodium 4-styrenesulfonate) (PSS) [32]. CPs polymerized with small dopants such as $\mathrm{LiClO}_{4}$ showed high structural regularity, a more compact internal structure, and higher conductivity and flexibility compared to those doped with larger dopants such as PSS and heparin $[32,194,198]$. The use of small-sized dopants, a high deposition charge density, and a high dopant concentration in the electrochemical polymerization solution was able to provide a rougher coating surface morphology [194]. However, the work from PoolWarren and co-workers showed that dopants with larger sizes may generate softer and lessadherent CP films [199]. The uniformity of the coating on the electrode sites also varies with the size of the dopants. PSS-doped PEDOT showed aggregation on the edge of the electrode sites, while $\mathrm{ClO}_{4}^{-}$and pTS-doped CPs showed more even coatings [194,195]. In order to improve the biocompatibility of CPs and reduce the tissue responses during implantation, bioactive molecules can be used as dopants and incorporated in the $\mathrm{CP}$ coating during electrochemical polymerization. Biologically active dopants-such as laminin peptide sequences, hyaluronic acid, or silk-like polymers with fibronectin fragments (SLPF) —can potentially enhance the biocompatibility and the cell adhesion on the surface of neural electrodes [200-202]. Cui et al. co-deposited PPy and synthetic-peptide DCDPGYIGSR on the electrode surface by using electrochemical polymerization (Figure 6c) [200]. The immunocytochemical studies indicated that the density of neurofilaments found by positive staining on the coated electrode was significantly higher than that on the uncoated electrode, indicating that the PPy/DCDPGYIGSR coating established strong interactions with the neuronal structure in vivo. The PPy film can significantly enhance the neurite outgrowth of PC12 cells by incorporating brain-derived nerve growth factor (BDNF) and nerve growth factor (NGF) [201]. Gomez and co-workers immobilized NGF on the surface of PPy using an intermediate linker, i.e., a layer of polyallylamine conjugated to an arylazido group (Figure 6d) [202]. Upon the application of electrical and chemical stimuli, the neurite lengths of PC12 cells cultured on the PPy-NGF film were much longer than the ones on the PPy film. Kim et al. reported the modification of the neural electrodes by the electrochemical copolymerization of polydopamine (PDA) and PPy to achieve enhanced biological performance [203]. PDA/PPy films were shown to have higher cell attachment and faster cell growth than the PPy films after 7 days of culturing. After the application of electrical stimulations, PC12 cells cultured on the PDA/PPy showed a significant promotion in neurite formation compared to the PPy films (Figure 6g). In addition to proteins and NGF, anti-inflammatory drugs like dexamethasone (DEX) can also be incorporated and released from $\mathrm{CP}$ coatings to reduce the tissue responses with improved electrode-tissue interactions [204].

The structural features of the $\mathrm{CP}$ coatings, such as their surface morphology and pore structure, play important roles in determining their electrical, mechanical and biological properties. A larger effective surface area is beneficial for the charge transfer between the electrode and electrolyte interface. Much research on the structural design and surface functionalization of the $\mathrm{CP}$ coatings were implemented to improve their performance. Martin's group employed monodispersed polystyrene latex spheres as templates to synthesize microporous PEDOT and PPy coatings on neural electrodes [205]. The corresponding electrochemical tests indicated that the impedance value of porous and rough $\mathrm{CP}$-coated electrodes was significantly lower than the bare gold electrodes over the whole range of frequencies, which coincided with an increase in the effective surface area because of the rough surface morphology. A nanotube-like $\mathrm{CP}$ coating was produced using electrospun nanofiber as a template. Firstly, poly(L-lactide) (PLLA) was deposited on the neural electrodes by electrospinning to form a nanofiber-templating layer. Then $\mathrm{CP}$ was electrochemically deposited on the PLLA nanofiber-coated neural electrodes. Afterwards, the PLLA nanofibers were removed using dichloromethane, leaving the $\mathrm{CP}$ nanotube-coated neural-coated electrode (Figure 6e) [206]. The impedance of the neural electrode was sharply decreased in the presence of the $\mathrm{CP}$ nanotubes. During the in vitro and in vivo recording tests, $\mathrm{CP}$ nanotube-coated neural electrodes showed more effective 
recording sites than the uncoated electrodes. In order to increase the integration in the electrode-tissue interface, a biomimetic, neuron-templated $\mathrm{CP}$ coating was reported by Richardson-Burns and coworkers [186]. They electrochemically deposited PEDOT around living cells, and the cells were removed from the PEDOT coating using enzymatic and mechanical disruption to form a cell-templated PEDOT film (Figure 6f). They speculated that the cell-templated surface with biomimetic topologies would be more biocompatible and cell-attractive.

(a)
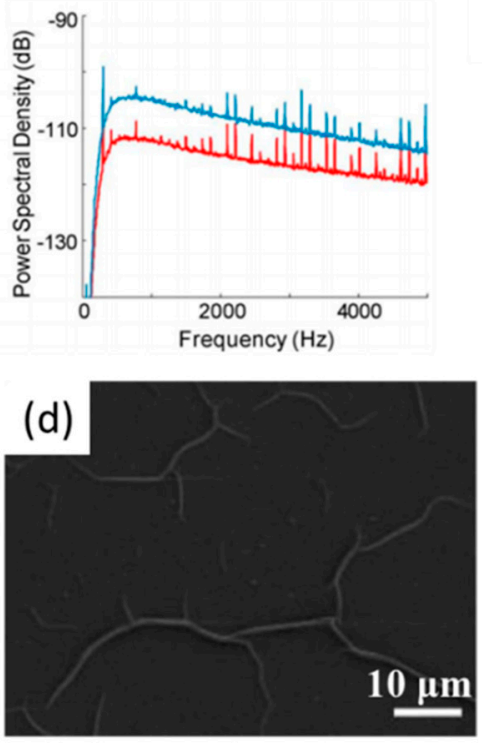

(g)

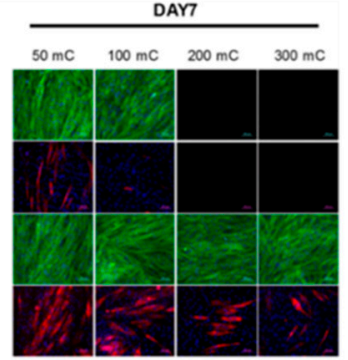

(b)
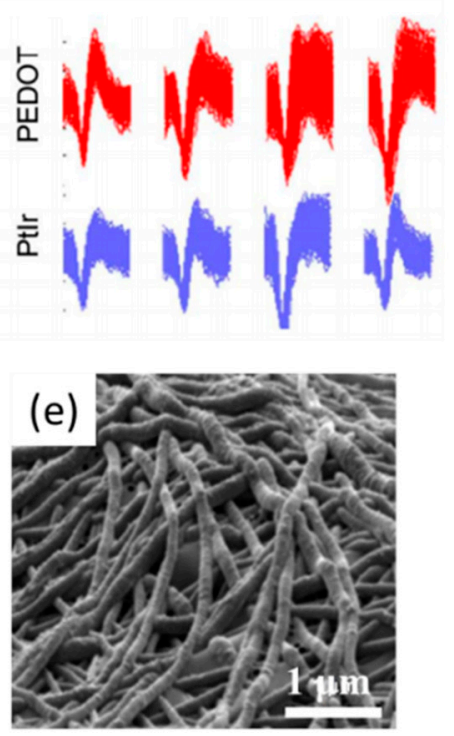

(h)

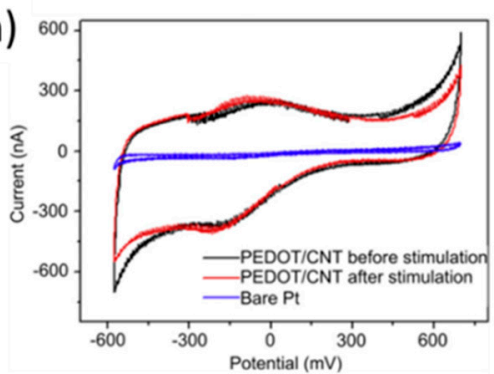

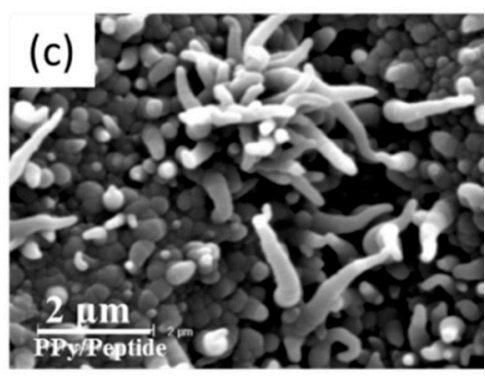

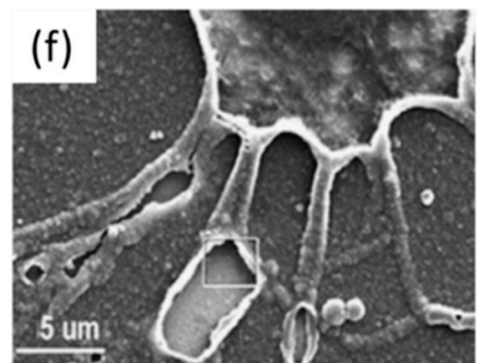

(i)

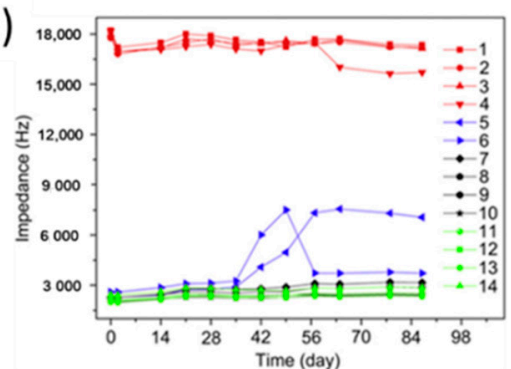

Figure 6. (a) Average power spectral density measured on the PEDOT and PtIr electrodes during surgery under high isoflurane. (b) 100 overlaid action potential waveforms ( $0.8 \mathrm{~ms}$ for each) recorded on different electrodes of the same array. $(\mathbf{a}, \mathbf{b})$ are reproduced with permission from [192], Copyright 2011, IEEE. The SEM image of the (c) PPy/DCDPGYIGSR, (d) PPy-NGF, (e) PEDOT nanotubes, and (f) cell-templated PEDOT coating. (c) is reproduced with permission from [200], Copyright 2003, Elsevier. (d) is reproduced with permission from [202], Copyright 2007, Wiley. (e) is reproduced with permission from [206], Copyright 2008, Elsevier. (f) is reproduced with permission from [187], Copyright 2007, Elsevier. (g) Immunofluorescence images of $\mathrm{C} 2 \mathrm{C} 12$ cells cultured on PPy and PDA/PPy samples for 7 days. The cells were stained for F-actin (green), MHC (red) and nuclei (blue). Scale bars $=200 \mu \mathrm{m}$. (g) is reproduced with permission from [203], Copyright 2018, ACS. (h) Cyclic voltammograms of a bare Pt electrode and PEDOT/CNT coated electrodes before and after long-term stimulation. (i) Monitored electrode impedance changes at $1 \mathrm{~K} \mathrm{~Hz}$ over time during three months of soaking in PBS. Plots 1-4 in red are bare Pt electrodes; plots 5-6 in blue are ultrathin PEDOT/CNT-coated (deposition charge less than $5 \mathrm{mC}) \mathrm{Pt}$ electrodes during stimulation; plots 7-10 in black and plots 11-14 in green are normal PEDOT/CNT-coated (deposition charge more than $10 \mathrm{mC})$ Pt electrodes with (7-10) and without (11-14) stimulations. $(\mathbf{h}, \mathbf{i})$ are reproduced with permission from [207], Copyright 2011, Elsevier.

Although $\mathrm{CP}$ coatings can reduce the impedance and increase the charge storage capacity of neural electrodes, the relatively weak electrochemical and mechanical stability of $\mathrm{CP}$ coatings remain a great challenge for chronic recording and stimulations. In order to improve the mechanical durability of the $\mathrm{CP}$ coatings, $\mathrm{CNTs}$ and graphene oxide have been 
used as the reinforcing materials in CP films. Due to the mechanically robust and highly conductive CNTs and graphene, the carbon-CP composite coatings showed both strong mechanical stability and high conductivity (Figure 6 h,i) $[207,208]$. The adhesion of CP to a neural electrode can also be enhanced by roughening the surface of neural electrodes in a pretreatment step [209]. Recently, PDA has also been utilized to improve the interaction between CP coatings and the neural electrode [210].

\section{Hydrogels}

Although the electrochemical properties of neural electrodes coated with nanostructured metallic, carbon-based and conducting polymeric materials have been significantly improved, the issue of the mechanical mismatch between electrodes and tissues, which may cause a series of inflammatory responses, still remains. Hydrogels, which have similar mechanical properties to biological tissue, high water contents, and good biocompatibility, have been considered as a promising coating candidate for neural interfacing. Hydrogels with optimal mechanical properties can serve as a buffer layer between the hard electrodes and soft tissues in order to reduce the adverse tissue responses induced by brain micromotion. Alginate [208], poly(ethylene glycol) (PEG) $[48,211]$ and poly(vinyl alcohol) (PVA) [212,213] hydrogels have been employed to reduce the degree of glial scarring and neural cell loss. Lu et al. synthesized poly(vinyl alcohol)/ poly(acrylic acid) interpenetrating polymer network (PVA/PAA IPNs) hydrogel coatings and investigated their feasibility for implantable neural electrodes [213]. PVA was chosen due to its excellent mechanical strength, good film formation property and stability in physiological conditions. The results of the protein adsorption tests indicated that the fibrinogen adsorption on the PVA/PAA IPNs coating was approximately seven times lower than the uncoated surface, as a result of the protein resistive PAA (Figure 7a). The non-specific adsorption of protein layers is considered harmful to the performance of neural electrodes. The number of astrocytes around the PVA/PAA IPN-coated implant was significantly lower than that of the control group after 6 weeks of implantation (Figure $7 \mathrm{~b}$ ). Lu et al. also investigated the effects of polyethylene glycol-containing polyurethane hydrogel coatings and polyurethane -poly(vinyl alcohol) hydrogel coatings in improving the biocompatibility of neural electrodes [211]. Furthermore, the incorporation of neurotrophins, neural adhesion molecules and anti-inflammatory drugs into hydrogel coatings has been proven to reduce the degree of astrogliosis and the loss of neuronal bodies around the neural implants.

However, due to the low electrical conductivities of pure hydrogel-based coatings, the electrochemical performance of the non-conducting hydrogel-coated electrodes was not significantly enhanced. For example, PVA-based and PEG-based hydrogel coatings may bring higher impendence values to the underlying neural electrodes. New strategies to enhance the electrochemical properties without compromising the advanced biomechanical features of hydrogel coatings can provide reliable solutions to further strengthen the tissue-electrode interfaces. Due to their nano- and micro-porous 3D polymeric network structures, the apparent properties of hydrogels, e.g., electrical properties, can be readily adjusted by adding different functional materials. Many electrically conducting materialsincluding CNTs, graphene, and conducting polymers-have been added into the hydrogel matrices to improve the electrical conductivity. Among the various conductive hydrogel coatings, conducting polymer-based hydrogel coatings have been widely used in neural interfacing, owing to their good electrochemical properties, biocompatibility, and ease of processing and preparation. Conducting polymers can be crosslinked with non-conducting hydrogel templates to form interpenetrating hydrogel networks (IPNs). With the addition of conducting polymers, the electrochemical properties of the hydrogel coating can be significant improved. Different types of hydrogels (such as the alginate hydrogel (HG), PEG hydrogel and polyacrylamide hydrogel) and conducting polymers (such as PEDOT, PPy and PANI) have been employed to form IPN hydrogel coatings for neural electrodes. Works by Kim et al. indicated that as PEDOT was deposited on the conductive sites of the neural electrode, the number of clearly detectable units and the values of SNR for 
the HG-coated electrode were restored to the original uncoated state [214]. They also found that the neural recording function of the electrode with a thicker HG coating was remarkably lost. Hassarati et al. evaluated the performance of PEDOT/PVA hydrogel coatings for cochlear implants [215]. The results showed that the CSC values $\left(124 \mathrm{mC} / \mathrm{cm}^{2}\right)$ of coated electrodes were approximately 10-times larger than that $\left(13 \mathrm{mC} / \mathrm{cm}^{2}\right)$ of the $\mathrm{Pt}$ electrode. Due to the good flexibility of the PEDOT/PVA hydrogel coating, the coated electrode could restore to the original shape after bending.

For neural interfacing, the adhesion between the hydrogel coating and neural electrode is considered one of the most vital factors that determines the reliability and lifetime of the neural device. The delamination of hydrogel coatings from the neural electrode's surface due to poor adhesion may lead to the failure of the neural electrode. Much research effort has been made to enhance the adhesion stability between the hydrogel coatings and the electrode substrate. Recently, strategies for achieving the strong adhesion of hydrogel coatings to the surface of neural electrodes by covalent bonding have been proposed. He et al. introduced a hybrid hydrogel coating composed of poly(ethylene glycol) diacrylate (PEGDA) and single-walled carbon nanotubes (SWNTs) [216]. In order to prepare the coating, a gold electrode was first modified with cysteamine (Cys), followed by Michael addition between Cys and PEGDA. The hybrid hydrogel coating was intact after $30 \mathrm{CV}$ cycles. Furthermore, the hybrid hydrogel coating did not detach from the gold electrode after ultrasonication for $15 \mathrm{~min}$, while the hydrogel coating without SWNTs detached after $10 \mathrm{~s}$ under ultrasonication. Moreover, the treatment of glass capillaries by 3-(trichlorosilyl) propyl methacrylate (TPM) for the improvement of the adhesion of PEG hydrogel was proposed by Spencer et al. (Figure 7c) [48]. Kleber et al. reported a method to produce conducting hydrogel attached to the surface of the conductive sites using 3-EBP silane [217]. The electrochemical stability of the conducting hydrogel was confirmed by a small decrease of the CSC ( 1.9\%) after $1000 \mathrm{CV}$ cycles; no delamination could be observed visually for the coating after ultrasonication (Figure $7 \mathrm{~d}, \mathrm{e})$. Although conducting hydrogel coatings can enhance the electrical and mechanical properties of neural microelectrodes, there are a few limitations for these hydrogel coatings regarding the capacity of facilitating neural regeneration to improve the integration of the electrode-nerve tissue interface. A new approach to embed neural cells into the hydrogel coatings of neural electrodes, called a "living electrode", was proposed to improve the neuron survival rate and minimize the formation of scar tissues [218-220]. The feasibility, electrical and mechanical properties of the living electrode in vitro were comprehensively characterized by R. A. Green and coworkers [218]. In their work, the Pt electrode was first coated with a conducting hydrogel $(\mathrm{CH})$ to improve its electrical properties, then a second hydrogel coating encapsulating the nerve cells was deposited on the $\mathrm{CH}$-coated Pt electrode. The second hydrogel coating was degradable, and the rate of degradation was expected to match the extension and growth rates of the neural cells in order to effectively form an integrated tissue-electrode interface with indistinct borders between the synthetic device and the surrounding tissues.

A 3D printing technique has also been used for the construction of advanced microstructured hydrogels which are suitable for neural electrode coatings. The typical 3D printing methods of hydrogel include inkjet printing [221], light-based printing [222] and extrusion-based printing [223]. For example, Jiang et al. fabricated a three-dimensional collagen/silk fibroin scaffold which can support the adhesion, elongation and differentiation of neural stem cells in vitro, and can promote the repair of injured the spinal cords of rats in vivo [224]. In order to mimic the real neural tissue, Kuzmenko et al. 3D-printed conductive nanocellulose-based scaffolds for in vitro neural tissue growth and assessment. The cell culture studies demonstrated that, compared to the pure nanocellulose, cells cultured on the conductive guidelines printed by the nanocellulose-based ink exhibited better proliferation and differentiation, which were probably induced by the ink's conductive property [225]. Rinoldi et al. designed a soft, biocompatible and conductive semi-IPN hydrogel which can improve the survival rates of neurons and astrocytes [222]. This hydrogel—as a 3D-printing ink—could be fabricated into micro-objects, which denotes 
a promising potential for novel neural tissue engineering applications. The resolutions of 3D printing technology vary from millimeters to submicrons. Thus, it is possible to precisely print the hydrogel coatings with specific morphologies and functions on the neural microelectrode by the 3D printing technique.
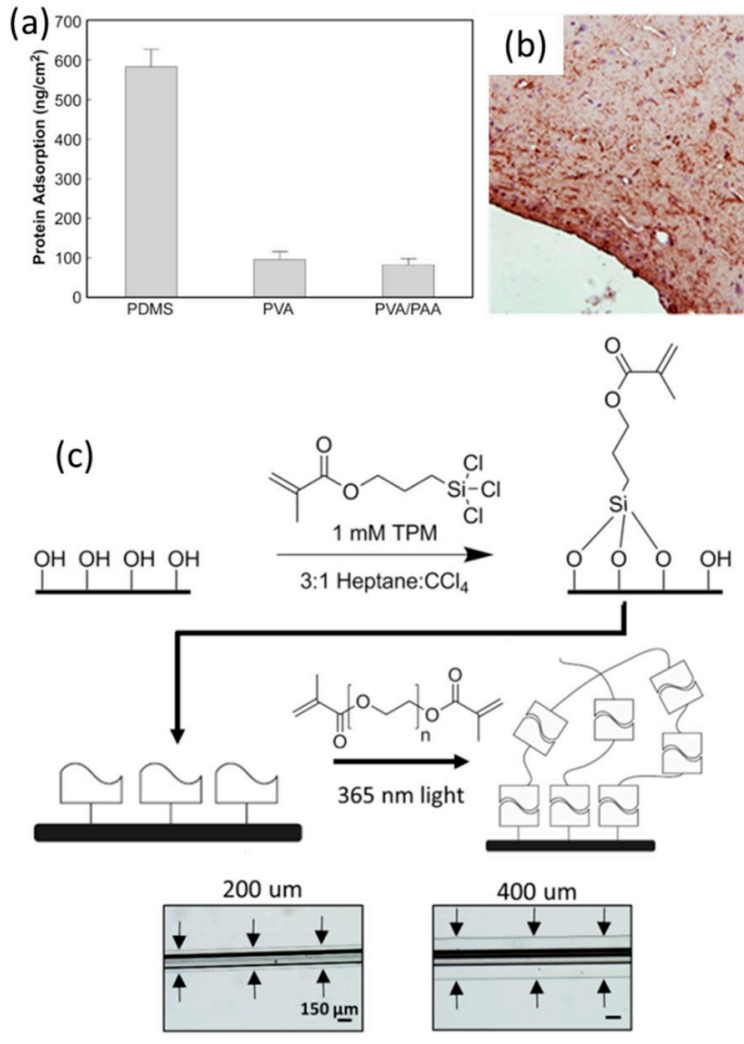
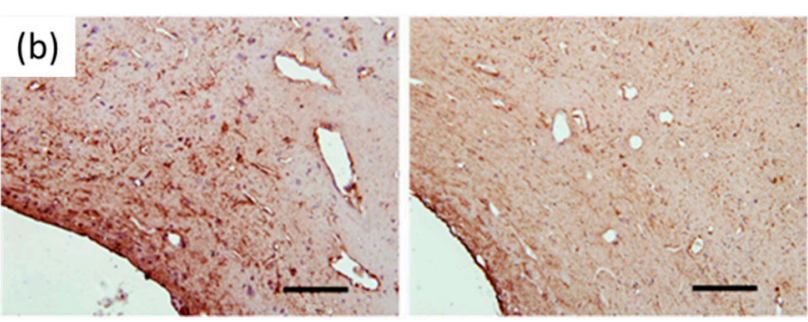

(d)

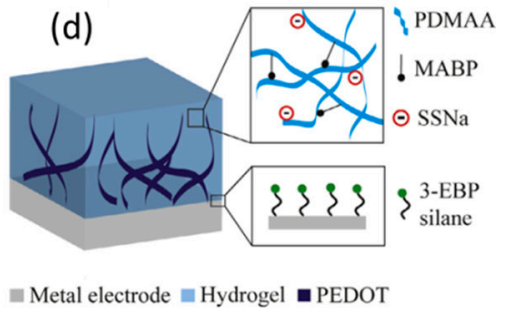

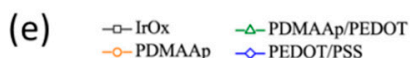

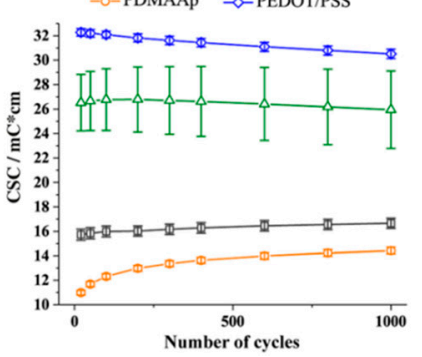

Figure 7. (a) Non-specific adsorption of protein (fibrinogen) on PDMS without a coating, with PVA coatings, and with PVA/PAA IPN (PAA/PVA $=10 \mathrm{~mol} \%$ ) film coatings $(n=3)$. (b) GFAP immunostaining of uncoated (left) and PVA/PAA IPN (PAA/PVA $=10 \mathrm{~mol} \%$ ) film-coated (right) PDMS implants after six weeks post-implantation $(\mathrm{bar}=50 \mathrm{~mm}) .(\mathbf{a}, \mathbf{b})$ are reproduced with permission from [213], Copyright 2009, Elsevier. (c) Soft PEG hydrogel coatings were formed on borosilicate glass capillaries through a multistep process. (c) is reproduced with permission from [48], Copyright 2017, Springer-Nature. (d) Schematic depiction of the CPH composition. The hydrogel component PDMAAp consists of the PDMAA backbone, the MABP crosslinker and the SSNa units, which serve as counterions during the deposition of PEDOT. The hydrogel is covalently attached to the surface with 3-EBP silane. (e) The mean CSC of the different coating materials is shown vs. repetitive cycling ( $n=1000$ cycles) in PBS. (d,e) are reproduced with permission from [217], Copyright 2017, Elsevier.

\section{Conclusions}

During the last few decades, various kinds of coating layers-which are designed to improve the electrical, mechanical and biological properties of the electrodes-have been used for neural interfacing. Lots of progress has been made, but many challenges-e.g., neural cell adhesion, neurite growth and chronic implantation-still exist in the way of pursuing a harmonious tissue-electrode interface. In order to improve the adhesion of neural cells on the surface of the coating, the surface microstructure and chemical composition of the coating can be modified to mimic the in vivo neural cells' living environment. Selected topological features and surface modifications of bioactive molecules/growth factors can also lead to optimal neurite growth and neuron adhesion on the surface of the coating.

Another challenge is how to improve the long-term stability of the coating in vivo. During implantation, the electrochemical properties of the coating deteriorate due to 
degradation. The delamination of the coating from the neural electrode may happen after repeated stimulations. Moreover, the mechanical friction between the coating and tissue induced by the brain micromotion may result in the delamination of the coating. In order to enhance the mechanical stability of the coating on the neural electrode, the strategy of introducing covalent bonding between the coating and the neural electrode can be utilized.

From a biological perspective, the neural electrode would be considered to be a foreign object by the immune system; the function of the electrode can be dramatically hindered by acute protein fouling and chronic scar formation, which set an intensive insulating barrier between the electrode and the surrounding tissue. The barrier significantly elevates the physical distance between the electrode and the neural cells, and thus attenuates the signal transmission and causes signal loss along the pathway. In order to reduce the protein absorption, new advanced materials with anti-fouling and good biocompatibility can be introduced as coatings. Recently, zwitterionic materials have been studied as coatings for neural electrodes due to their superior resistance to nonspecific protein adsorption (less than $0.3 \mathrm{ng} \mathrm{cm}^{-2}$ ). Cui's group grafted zwitterionic polymer poly(sulfobetaine methacrylate) (PSB) onto the silicon implant's surface using a biomimetic catechol group [226]. The results of the in vivo tissue response tests showed fewer microglia and macrophages around the PSB-coated neural electrode compared to the bare electrodes. More importantly, fewer activated astrocytes were observed around the PSB-coated electrode compared to the control after 1 week of implantation, suggesting that the PSB coating may have the ability to enhance the duration of neural electrodes. Future research effort should aim to produce a tissue-electrode interface with high cell affinity. Multifunctional nanostructured composite coatings with excellent biomechanical and electrochemical properties, and capable of imitating the cell surface structure, will benefit the design of an ideal tissue-electrode interface.

Author Contributions: Conceptualization, P.Y. and Y.L., writing-original draft preparation, P.Y.; writing-review and editing, Y.L. and L.X.; supervision, C.Z.; funding acquisition, Y.L. All authors have read and agreed to the published version of the manuscript.

Funding: This research was funded by Guangdong Science and Technology Department, grant number 2018A030310075; National Natural Science Foundation of China, grant number 81801851; China Postdoctoral Science Foundation, grant number 2018M633230 and Sun Yat-sen University.

Institutional Review Board Statement: Not applicable.

Informed Consent Statement: Not applicable.

Data Availability Statement: Data sharing not applicable.

Conflicts of Interest: The authors declare no conflict of interest.

\section{References}

1. Morin, F.O.; Takamura, Y.; Tamiya, E. Investigating neuronal activity with planar microelectrode arrays: Achievements and new perspectives. J. Biosci. Bioeng. 2005, 100, 131-143. [CrossRef] [PubMed]

2. Priori, A.; Foffani, G.; Pesenti, A.; Bianchi, A.; Chiesa, V.; Baselli, G.; Caputo, E.; Tamma, F.; Rampini, P.; Egidi, M.; et al. Movement-related modulation of neural activity in human basal ganglia and its L-DOPA dependency: Recordings from deep brain stimulation electrodes in patients with Parkinson's disease. Neurol. Sci. 2002, 23, s101-s102. [CrossRef]

3. Shepherd, R.K.; Hatsushika, S.; Clark, G.M. Electrical stimulation of the auditory nerve: The effect of electrode position on neural excitation. Hear. Res. 1993, 66, 108-120. [CrossRef]

4. Zrenner, E.; Bartz-Schmidt, K.U.; Benav, H.; Besch, D.; Bruckmann, A.; Gabel, V.P.; Gekeler, F.; Greppmaier, U.; Harscher, A.; Kibbel, S.; et al. Subretinal electronic chips allow blind patients to read letters and combine them to words. Proc. R. Soc. B 2011, 278, 1489-1497. [CrossRef] [PubMed]

5. Truccolo, W.; Donoghue, J.A.; Hochberg, L.R.; Eskandar, E.N.; Madsen, J.R.; Anderson, W.S.; Brown, E.N.; Halgren, E.; Cash, S.S. Single-neuron dynamics in human focal epilepsy. Nat. Neurosci. 2011, 14, 635. [CrossRef]

6. Caparros-Lefebvre, D.; Blond, S.; Feltin, M.; Pollak, P.; Benabid, A.L. Improvement of levodopa induced dyskinesias by thalamic deep brain stimulation is related to slight variation in electrode placement: Possible involvement of the centre median and parafascicularis complex. J. Neurol. Neurosurg. Psychiatry 1999, 67, 308-314. [CrossRef] [PubMed] 
7. Shahrokhi, F.; Abdelhalim, K.; Serletis, D.; Carlen, P.L.; Genov, R. The 128-channel fully differential digital integrated neural recording and stimulation interface. IEEE Trans. Biomed. Circuits Syst. 2010, 4, 149-161. [CrossRef]

8. Mavoori, J.; Jackson, A.; Diorio, C.; Fetz, E. An autonomous implantable computer for neural recording and stimulation in unrestrained primates. J. Neurosci. Methods 2005, 148, 71-77. [CrossRef]

9. Kim, J.H.; Kang, G.; Nam, Y.; Choi, Y.K. Surface-modified microelectrode array with flake nanostructure for neural recording and stimulation. Nanotechnology 2010, 21, 085303. [CrossRef]

10. Ortmann, V.; Baziyan, B.K. Intracortical neural interface for prosthetic applications. In Proceedings of the 29th Annual International Conference of the IEEE Engineering in Medicine and Biology Society (IEEE), Lyon, France, 23-26 August 2007; pp. 6371-6374.

11. Summerlee, A.J.S.; Paisley, A.C.; Goodall, C.L. A method for determining the position of chronically implanted platinum microwire electrodes. J. Neurosci. Methods 1982, 5, 7-11. [CrossRef]

12. Sankar, V.; Patrick, E.; Dieme, R.; Sanchez, J.C.; Prasad, A.; Nishida, T. Electrode impedance analysis of chronic tungsten microwire neural implants: Understanding abiotic vs. biotic contributions. Front. Neuroeng. 2014, 7, 13. [CrossRef] [PubMed]

13. Zhang, C.; Driver, N.; Tian, Q.; Jiang, W.; Liu, H. Electrochemical deposition of conductive polymers onto magnesium microwires for neural electrode applications. J. Biomed. Mater. Res. 2018, 106, 1887-1895. [CrossRef] [PubMed]

14. Zhang, C.; Wen, T.H.; Razak, K.A.; Lin, J.; Xu, C.; Seo, C.; Villafana, E.; Jimenez, H.; Liu, H. Magnesium-based biodegradable microelectrodes for neural recording. Mater. Sci. Eng. C 2020, 110, 110614. [CrossRef]

15. Bareket-Keren, L.; Hanein, Y. Carbon nanotube-based multi electrode arrays for neuronal interfacing: Progress and prospects. Front. Neural Circuits 2013, 6, 122. [CrossRef]

16. Chen, C.H.; Lin, C.T.; Hsu, W.L.; Chang, Y.C.; Yeh, S.R.; Li, L.J.; Yao, D.J. A flexible hydrophilic-modified graphene microprobe for neural and cardiac recording. Nanomed. Nanotechnol. Biol. Med. 2013, 9, 600-604. [CrossRef]

17. Cui, X.; Hetke, J.F.; Wiler, J.A.; Anderson, D.J.; Martin, D.C. Electrochemical deposition and characterization of conducting polymer polypyrrole/PSS on multichannel neural probes. Sens. Actuators A Phys. 2001, 93, 8-18. [CrossRef]

18. Wark, H.A.C.; Mathews, K.S.; Normann, R.A.; Fernandez, E. Behavioral and cellular consequences of high-electrode count Utah Arrays chronically implanted in rat sciatic nerve. J. Neural Eng. 2014, 11, 046027. [CrossRef]

19. Fekete, Z. Recent advances in silicon-based neural microelectrodes and microsystems: A review. Sens. Actuators B Chem. 2015, 215, 300-315. [CrossRef]

20. Brunton, E.K.; Winther-Jensen, B.; Wang, C.; Yan, E.B.; Gooie, S.H.; Lowery, A.J.; Rajan, R. In Vivo comparison of the charge densities required to evoke motor responses using novel annular penetrating microelectrodes. Front. Neurosci. 2015, 9, 265 [CrossRef] [PubMed]

21. Zhao, S.Y.; Liu, X.J.; Xu, Z.; Ren, H.Y.; Deng, B.; Tang, M.; Lu, L.L.; Fu, X.F.; Peng, H.L.; Liu, Z.F.; et al. Graphene encapsulated copper microwires as highly MRI compatible neural electrodes. Nano Lett. 2016, 16, 7731-7738. [CrossRef]

22. Martin, D.C. Molecular design, synthesis, and characterization of conjugated polymers for interfacing electronic biomedical devices with living tissue. MRS Commun. 2015, 5, 131-153. [CrossRef]

23. Nolta, N.F.; Christensen, M.B.; Crane, P.D.; Skousen, J.L.; Tresco, P.A. BBB leakage, astrogliosis, and tissue loss correlate with silicon microelectrode array recording performance. Biomaterials 2015, 53, 753-762. [CrossRef]

24. Winslow, B.D.; Tresco, P.A. Quantitative analysis of the tissue response to chronically implanted microwire electrodes in rat cortex. Biomaterials 2010, 31, 1558-1567.

25. Frank, J.A.; Antonini, M.J.; Anikeeva, P. Next-generation interfaces for studying neural function. Nat. Biotechnol. 2019, 37, 1013-1023. [CrossRef]

26. Lee, M.; Shim, H.J.; Choi, C.; Kim, D.H. Soft high-resolution neural interfacing probes: Materials and design approaches. Nano Lett. 2019, 19, 2741-2749. [PubMed]

27. Blau, A.; Murr, A.; Wolff, S.; Sernagor, E.; Medini, P.; Iurilli, G.; Ziegler, C.; Benfenati, F. Flexible, all-polymer microelectrode arrays for the capture of cardiac and neuronal signals. Biomaterials 2011, 32, 1778-1786.

28. Cuttaz, E.A.; Chapman, C.A.R.; Syed, O.; Goding, J.A.; Green, R.A. Stretchable, fully polymeric electrode arrays for peripheral nerve stimulation. Adv. Sci. 2021, 8, 2004033. [CrossRef]

29. Lee, K.; Singh, A.; He, J.; Massia, S.; Kim, B.; Raupp, G. Polyimide based neural implants with stiffness improvement. Sens. Actuators B Chem. 2004, 102, 67-72.

30. Hsu, J.M.; Rieth, L.; Normann, R.A.; Tathireddy, P.; Solzbacher, F. Encapsulation of an integrated neural interface device with Parylene C. IEEE Trans. Biomed. Eng. 2008, 56, 23-29. [CrossRef]

31. Cuttaz, E.; Goding, J.; Vallejo-Giraldo, C.; Aregueta-Robles, U.; Lovell, N.; Ghezzi, D.; Green, R.A. Conductive elastomer composites for fully polymeric, flexible bioelectronics. Biomater. Sci. 2019, 7, 1372-1385. [CrossRef]

32. Fonner, J.M.; Forciniti, L.; Nguyen, H.; Byrne, J.D.; Kou, Y.F.; Syeda-Nawaz, J.; Schmidt, C.E. Biocompatibility implications of polypyrrole synthesis techniques. Biomed. Mater. 2008, 3, 034124. [CrossRef]

33. Hou, H.; Li, F.; Su, Z.; Yin, J.; Jiang, X. Light-reversible hierarchical patterns by dynamic photo-dimerization induced wrinkles. J. Mater. Chem. C 2017, 5, 8765-8773. [CrossRef]

34. Polikov, V.S.; Tresco, P.A.; Reichert, W.M. Response of brain tissue to chronically implanted neural electrodes. J. Neurosci. Methods 2005, 148, 1-18. [CrossRef] 
35. Lagoa, C.E.; Bartels, J.; Baratt, A.; Tseng, G.; Clermont, G.; Fink, M.P.; Billiar, T.R.; Vodovotz, Y. The role of initial trauma in the host's response to injury and hemorrhage: Insights from a correlation of mathematical simulations and hepatic transcriptomic analysis. Shock 2006, 26, 592-600. [CrossRef] [PubMed]

36. Marin, C.; Fernández, E. Biocompatibility of intracortical microelectrodes: Current status and future prospects. Front. Neuroeng. 2010, 3, 8. [CrossRef]

37. Leach, J.B.; Achyuta, A.K.H.; Murthy, S.K. Bridging the divide between neuroprosthetic design, tissue engineering and neurobiology. Front. Neuroeng. 2010, 2, 18. [CrossRef]

38. Szarowski, D.H.; Andersen, M.D.; Retterer, S.; Spence, A.J.; Isaacson, M.; Craighead, H.G.; Turner, J.N.; Shain, W. Brain responses to micro-machined silicon devices. Brain Res. 2003, 983, 23-35. [CrossRef]

39. Streit, W.J.; Xue, Q.S. Life and death of microglia. J. Neuroimmune Pharmacol. 2009, 4, 371. [CrossRef]

40. Saadoun, S.; Papadopoulos, M.C.; Watanabe, H.; Yan, D.; Manley, G.T.; Verkman, A.S. Involvement of aquaporin-4 in astroglial cell migration and glial scar formation. J. Cell Sci. 2005, 118, 5691-5698. [CrossRef]

41. Yoshida, S.; Yoshida, A.; Ishibashi, T.; Elner, S.G.; Elner, V.M. Role of MCP-1 and MIP-1 $\alpha$ in retinal neovascularization during postischemic inflammation in a mouse model of retinal neovascularization. J. Leukoc. Biol. 2003, 73, 137-144. [CrossRef] [PubMed]

42. Chen, Y.; Swanson, R.A. Astrocytes and brain injury. J. Cereb. Blood Flow Metab. 2003, 23, 137-149. [CrossRef]

43. Halpern, M.E.; Fallon, J. Current waveforms for neural stimulation-charge delivery with reduced maximum electrode voltage. IEEE Trans. Biomed. Eng. 2010, 57, 2304-2312. [CrossRef] [PubMed]

44. McConnell, G.C.; Rees, H.D.; Levey, A.I.; Gutekunst, C.A.; Gross, R.E.; Bellamkonda, R.V. Implanted neural electrodes cause chronic, local inflammation that is correlated with local neurodegeneration. J. Neural Eng. 2009, 6, 056003. [CrossRef] [PubMed]

45. Turner, J.N.; Shain, W.; Szarowski, D.H.; Andersen, M.; Martins, S.; Isaacson, M.; Craighead, H. Cerebral astrocyte response to micromachined silicon implants. Exp. Neurol. 1999, 156, 33-49. [CrossRef]

46. Griffith, R.W.; Humphrey, D.R. Long-term gliosis around chronically implanted platinum electrodes in the Rhesus macaque motor cortex. Neurosci. Lett. 2006, 406, 81-86. [CrossRef]

47. Salatino, J.W.; Ludwig, K.A.; Kozai, T.D.Y.; Purcell, E.K. Glial responses to implanted electrodes in the brain. Nat. Biomed. Eng. 2017, 1, 862-877. [CrossRef]

48. Spencer, K.C.; Sy, J.C.; Ramadi, K.B.; Graybiel, A.M.; Langer, R.; Cima, M.J. Characterization of mechanically matched hydrogel coatings to improve the biocompatibility of neural implants. Sci. Rep. 2017, 7, 1952. [CrossRef]

49. Beamish, F.E. The Analytical Chemistry of the Noble Metals; Elsevier: Amsterdam, The Netherlands, 2013 ; Chapter 1.

50. Riistama, J.; Lekkala, J. Electrode-electrolyte interface properties in implantation conditions. In Proceedings of the 28th Annual International Conference of the IEEE Engineering in Medicine and Biology Society (IEEE), New York, NY, USA, 31 August-3 September 2006; pp. 6021-6024.

51. Boretius, T.; Jurzinsky, T.; Koehler, C.; Kerzenmacher, S.; Hillebrecht, H.; Stieglitz, T. High-porous platinum electrodes for functional electrical stimulation. In Proceedings of the 33rd Annual International Conference of the IEEE Engineering in Medicine and Biology Society (IEEE), Boston, MA, USA, 30 August-3 September 2011; pp. 5404-5407.

52. Chen, N.; Tian, L.; Patil, A.C.; Peng, S.; Yang, I.H.; Thakor, N.V.; Ramakrishna, S. Neural interfaces engineered via micro-and nanostructured coatings. Nanotoday 2017, 14, 59-83. [CrossRef]

53. Boehler, C.; Vieira, D.M.; Egert, U.; Asplund, M. NanoPt-A nanostructured electrode coating for neural recording and microstimulation. ACS Appl. Mater. Interfaces 2020, 12, 14855-14865. [CrossRef]

54. de Haro, C.; Mas, R.; Abadal, G.; Munoz, J.; Perez-Murano, F.; Domínguez, C. Electrochemical platinum coatings for improving performance of implantable microelectrode arrays. Biomaterials 2002, 23, 4515-4521. [CrossRef]

55. Negi, S.; Bhandari, R.; Rieth, L.; Solzbacher, F. In Vitro comparison of sputtered iridium oxide and platinum-coated neural implantable microelectrode arrays. Biomed. Mater. 2010, 5, 015007. [CrossRef] [PubMed]

56. Robblee, L.S. Iridium Oxide Coated Electrodes for Neural Stimulation. U.S. Patent 4,677,989, 7 July 1987.

57. Petrossians, A.; Whalen, J.J.; Weiland, J.D.; Mansfeld, F. Surface modification of neural stimulating/recording electrodes with high surface area platinum-iridium alloy coatings. In Proceedings of the 33rd Annual International Conference of the IEEE Engineering in Medicine and Biology Society (IEEE), Boston, MA, USA, 30 August-3 September 2011; pp. 3001-3004.

58. Leber, M.; Bhandari, R.; Mize, J.; Warren, D.J.; Shandhi, M.M.H.; Solzbacher, F.; Negi, S. Long term performance of porous platinum coated neural electrodes. Biomed. Microdevices 2017, 19, 62. [CrossRef]

59. Regehr, W.G.; Pine, J.; Rutledge, D.B. A long-term In Vitro silicon-based microelectrode-neuron connection. IEEE Trans. Biomed. Eng. 1988, 35, 1023-1032. [CrossRef]

60. Zhang, C.; Liu, J.Q.; Tian, H.C.; Kang, X.Y.; Du, J.C.; Rui, Y.F.; Yang, B.; Yang, C.S. Implantable electrode array with platinum black coating for brain stimulation in fish. Microsyst. Technol. 2015, 21, 139-145. [CrossRef]

61. Kovacs, G.T.A.; Storment, C.W.; Halks-Miller, M.; Belczynski, C.R.; Santina, C.C.D.; Lewis, E.R.; Maluf, N.I. Silicon-substrate microelectrode arrays for parallel recording of neural activity in peripheral and cranial nerves. IEEE Trans. Biomed. Eng. 1994, 41, 567-577. [CrossRef]

62. Borkholder, D.A.; Bao, J.; Maluf, N.I.; Perl, E.R.; Kovacs, G.T.A. Microelectrode arrays for stimulation of neural slice preparations. J. Neurosci. Methods 1997, 77, 61-66. [CrossRef]

63. Heim, M.; Yvert, B.; Kuhn, A. Nanostructuration strategies to enhance microelectrode array (MEA) performance for neuronal recording and stimulation. J. Physiol. Paris 2012, 106, 137-145. [CrossRef] 
64. Desai, S.A.; Rolston, J.D.; Guo, L.; Potter, S.M. Improving impedance of implantable microwire multi-electrode arrays by ultrasonic electroplating of durable platinum black. Front. Neuroeng. 2010, 3, 5. [CrossRef]

65. Marrese, C.A. Preparation of strongly adherent platinum black coatings. Anal. Chem. 1987, 59, 217-218. [CrossRef]

66. Marrese, C.A. Electrochemical Plating of Platinum Black Utilizing Ultrasonic Agitation. U.S. Patent 4,750,977, 14 June 1988.

67. Tang, R.; Pei, W.; Chen, S.; Zhao, H.; Chen, Y.; Han, Y.; Wang, C.; Chen, H. Fabrication of strongly adherent platinum black coatings on microelectrodes array. Sci. China Inform. Sci. 2014, 57, 1-10. [CrossRef]

68. Marzouk, S.A.M. Improved electrodeposited iridium oxide $\mathrm{pH}$ sensor fabricated on etched titanium substrates. Anal. Chem. 2003, 75, 1258-1266. [CrossRef]

69. Schuettler, M.; Doerge, T.; Wien, S.L.; Becker, S.; Staiger, A.; Hanauer, M.; Kammer, S.; Stieglitz, T. Cytotoxicity of platinum black. In Proceedings of the 10th Annual Conference of the International Functional Electrical Stimulation Society, Montreal, QC, Canada, 5-8 July 2005; pp. 343-345.

70. Heim, M.; Rousseau, L.; Reculusa, S.; Urbanova, V.; Mazzocco, C.; Joucla, S.; Bouffier, L.; Vytras, K.; Bartlett, P.; Kuhn, A.; et al. Combined macro-/mesoporous microelectrode arrays for low-noise extracellular recording of neural networks. J. Neurophysiol. 2012, 108, 1793-1803. [CrossRef] [PubMed]

71. Boehler, C.; Stieglitz, T.; Asplund, M. Nanostructured platinum grass enables superior impedance reduction for neural microelectrodes. Biomaterials 2015, 67, 346-353. [CrossRef]

72. Nakanishi, H.; Kikuta, I.; Teraji, S.; Norisuye, T.; Tran-Cong-Miyata, Q. Effects of nanowire length on charge transport in vertically aligned gold nanowire array electrodes. Langmuir 2018, 34, 15674-15680. [CrossRef]

73. Chapman, C.A.; Chen, H.; Stamou, M.; Biener, J.; Biener, M.M.; Lein, P.J.; Seker, E. Nanoporous gold as a neural interface coating: Effects of topography, surface chemistry, and feature size. ACS Appl. Mater. Interfaces 2015, 7, 7093-7100. [CrossRef]

74. Zhang, H.; Shih, J.; Zhu, J.; Kotov, N.A. Layered nanocomposites from gold nanoparticles for neural prosthetic devices. Nano Lett. 2012, 12, 3391-3398. [CrossRef]

75. Tybrandt, K.; Khodagholy, D.; Dielacher, B.; Renz, A.F.; Buzsaki, G.; Voros, J. High-density stretchable electrode grids for chronic neural recording. Adv. Mater. 2018, 30, e1706520. [CrossRef]

76. Paik, S.J.; Park, Y.; Cho, D. Roughened polysilicon for low impedance microelectrodes in neural probes. J. Micromech. Microeng. 2003, 13, 373. [CrossRef]

77. Seker, E.; Berdichevsky, Y.; Begley, M.R.; Reed, M.L.; Staley, K.J.; Yarmush, M.L. The fabrication of low-impedance nanoporous gold multiple-electrode arrays for neural electrophysiology studies. Nanotechnology 2010, 21, 125504. [CrossRef]

78. Yoon, H.; Hankins, P.; Oh, S.; Harbaugh, R.E.; Varadan, V.K. Heterostructured $\mathrm{IrO}_{2} / \mathrm{Au}$ nanowire electrodes and unit recordings from hippocampal rat brain. J. Nanotech. Eng. Med. 2010, 1, 021006. [CrossRef]

79. Nyce, G.W.; Hayes, J.R.; Hamza, A.V.; Satcher, J.H. Synthesis and characterization of hierarchical porous gold materials. Chem. Mater. 2007, 19, 344-346. [CrossRef]

80. Wan, D.; Xia, X.; Wang, Y.; Xia, Y. Robust synthesis of gold cubic nanoframes through a combination of galvanic replacement, gold deposition, and silver dealloying. Small 2013, 9, 3111-3117. [CrossRef]

81. Lavrik, N.V.; Tipple, C.A.; Sepaniak, M.J.; Datskos, P.G. Gold nano-structures for transduction of biomolecular interactions into micrometer scale movements. Biomed. Microdevices 2001, 3, 35-44. [CrossRef]

82. Mescola, A.; Canale, C.; Prato, M.; Diaspro, A.; Berdondini, L.; Maccione, A.; Dante, S. Specific neuron placement on gold and silicon nitride-patterned substrates through a two-step functionalization method. Langmuir 2016, 32, 6319-6327. [CrossRef] [PubMed]

83. Yoo, J.M.; Negi, S.; Tathireddy, P.; Solzbacher, F.; Song, J.I.; Rieth, L.W. Excimer laser deinsulation of Parylene-C on iridium for use in an activated iridium oxide film-coated Utah electrode array. J. Neurosci. Methods 2013, 215, 78-87. [CrossRef] [PubMed]

84. Meyer, R.D.; Cogan, S.F.; Nguyen, T.H.; Rauh, R.D. Electrodeposited iridium oxide for neural stimulation and recording electrodes. IEEE Trans. Neural Syst. Rehabil. Eng. 2001, 9, 2-11. [CrossRef]

85. Cogan, S.F.; Ehrlich, J.; Plante, T.D.; Smirnov, A.; Shire, D.B.; Gingerich, M.; Rizzo, J.F. Sputtered iridium oxide films for neural stimulation electrodes. J. Biomed. Mater. Res. B Appl. Biomater. 2009, 89, 353-361. [CrossRef]

86. Cogan, S.F.; Troyk, P.R.; Ehrlich, J.; Plante, T.D.; Detlefsen, D.E. Potential-biased, asymmetric waveforms for charge-injection with activated iridium oxide (AIROF) neural stimulation electrodes. IEEE Trans. Biomed. Eng. 2006, 53, 327-332. [CrossRef] [PubMed]

87. Cogan, S.F.; Plante, T.; Ehrlich, J. Sputtered iridium oxide films (SIROFs) for low-impedance neural stimulation and recording electrodes. In Proceedings of the 26th Annual International Conference of the IEEE Engineering in Medicine and Biology Society (IEEE), San Francisco, CA, USA, 1-4 September 2004; pp. 4153-4156.

88. Chen, Y.M.; Chung, T.W.; Wu, P.W.; Chen, P.C. A cost-effective fabrication of iridium oxide films as biocompatible electrostimulation electrodes for neural interface applications. J. Alloys Compd. 2017, 692, 339-345. [CrossRef]

89. Eick, S.; Wallys, J.; Hofmann, B.; Ooyen, A.; Schnakenberg, U.; Ingebrandt, S.; Offenhäusser, A. Iridium oxide microelectrode arrays for in vitro stimulation of individual rat neurons from dissociated cultures. Front. Neuroeng. 2009, 2, 16. [CrossRef]

90. Gawad, S.; Giugliano, M.; Heuschkel, M.; Wessling, B.; Markram, H.; Schnakenberg, U.; Renaud, P.; Morgan, H. Substrate arrays of iridium oxide microelectrodes for in vitro neuronal interfacing. Front. Neuroeng. 2009, 2, 1. [CrossRef]

91. Cruz, A.M.; Abad, L.; Carretero, N.M.; Moral-Vico, J.; Fraxedas, J.; Lozano, P.; Subías, G.; Padial, V.; Carballo, M.; Collazos-Castro, J.E.; et al. Iridium oxohydroxide, a significant member in the family of iridium oxides. Stoichiometry, characterization, and implications in bioelectrodes. J. Phys. Chem. C 2012, 116, 5155-5168. [CrossRef] 
92. Katsube, T.; Lauks, I.; Zemel, J.N. pH-sensitive sputtered iridium oxide films. Sens. Actuators 1981, 2, 399-410. [CrossRef]

93. Wang, K.; Liu, C.C.; Durand, D.M. Flexible nerve stimulation electrode with iridium oxide sputtered on liquid crystal polymer. IEEE Trans. Biomed. Eng. 2009, 56, 6-14. [CrossRef]

94. Haas, J.; Rudorf, R.; Becker, M.; Daschner, R.; Drzyzga, A.; Burkhardt, C.; Stett, A. Sputtered iridium oxide as electrode material for subretinal stimulation. Sens. Mater. 2020, 32, 2903-2918. [CrossRef]

95. Zhou, H.H.; Li, T.; Duan, Y.W.Y. Reduce impedance of intracortical iridium oxide microelectrodes by hydrogel coatings. Sens. Actuators B Chem. 2012, 161, 198-202. [CrossRef]

96. Mailley, S.C.; Hyland, M.; Mailley, P.; McLaughlin, J.M.; McAdams, E.T. Electrochemical and structural characterizations of electrodeposited iridium oxide thin-film electrodes applied to neurostimulating electrical signal. Mater. Sci. Eng. C 2002, 21, 167-175. [CrossRef]

97. Lu, Y.; Wang, T.; Cai, Z.; Cao, Y.; Yang, H.; Duan, Y.Y. Anodically electrodeposited iridium oxide films microelectrodes for neural microstimulation and recording. Sens. Actuators B Chem. 2009, 137, 334-339. [CrossRef]

98. Deku, F.; Joshi-Imre, A.; Mertiri, A.; Gardner, T.J.; Cogan, S.F. Electrodeposited iridium oxide on carbon fiber ultramicroelectrodes for neural recording and stimulation. J. Electrochem. Soc. 2018, 165, D375. [CrossRef]

99. Cogan, S.F.; Guzelian, A.A.; Agnew, W.F.; Yuen, T.G.; McCreery, D.B. Over-pulsing degrades activated iridium oxide films used for intracortical neural stimulation. J. Neurosci. Methods 2004, 137, 141-150. [CrossRef]

100. Chen, C.; Ruan, S.C.; Bai, X.; Lin, C.M.; Xie, C.G.; Lee, I.S. Patterned iridium oxide film as neural electrode interface: Biocompatibility and improved neurite outgrowth with electrical stimulation. Mater. Sci. Eng. C Mater. Biol. Appl. 2019, 103. [CrossRef] [PubMed]

101. McLean, G. Activated Iridium Oxide Electrodes and Methods for Their Fabrication. U.S. Patent Application No. 11/031,669, 6 July 2006.

102. Lu, Y.; Cai, Z.; Cao, Y.; Yang, H.; Duan, Y.Y. Activated iridium oxide films fabricated by asymmetric pulses for electrical neural microstimulation and recording. Electrochem. Commun. 2008, 10, 778-782. [CrossRef]

103. Ryynänen, T.; Ylä-Outinen, L.; Narkilahti, S.; Tanskanen, J.M.; Hyttinen, J.; Hämäläinen, J.; Leskelä, M.; Lekkala, J. Atomic layer deposited iridium oxide thin film as microelectrode coating in stem cell applications. J. Vac. Sci. Technol. A 2012, $30,041501$. [CrossRef]

104. Singh, K.; Abooameri, F.; Sivaramakrishnan, V.; Sajoto, T.; Lim, V.; Zhao, J. Iridium and Iridium Oxide Electrodes Used in Ferroelectric Capacitors. U.S. Patent Application No. 09/749,262, 20 June 2002.

105. Comstock, D.J.; Christensen, S.T.; Elam, J.W.; Pellin, M.J.; Hersam, M.C. Synthesis of nanoporous activated iridium oxide films by anodized aluminum oxide templated atomic layer deposition. Electrochem. Commun. 2010, 12, 1543-1546. [CrossRef]

106. Zeng, Q.; Xia, K.; Sun, B.; Yin, Y.; Wu, T.; Humayun, M.S. Electrodeposited iridium oxide on platinum nanocones for improving neural stimulation microelectrodes. Electrochim. Acta 2017, 237, 152-159. [CrossRef]

107. Kang, X.; Liu, J.; Tian, H.; Zhang, C.; Yang, B.; NuLi, Y.; Zhu, H.; Yang, C. Controlled activation of iridium film for AIROF microelectrodes. Sens. Actuators B Chem. 2014, 190, 601-611. [CrossRef]

108. Kim, R.; Nam, Y. Novel platinum black electroplating technique improving mechanical stability. In Proceedings of the 35th Annual International Conference of the IEEE Engineering in Medicine and Biology Society (EMBC), Osaka, Japan, 3-7 July 2013; pp. 184-187.

109. Negi, S.; Bhandari, R.; Rieth, L.; Van Wagenen, R.; Solzbacher, F. Neural electrode degradation from continuous electrical stimulation: Comparison of sputtered and activated iridium oxide. J. Neurosci. Methods 2010, 186, 8-17. [CrossRef]

110. Kim, T.; Cho, M.; Yu, K. Flexible and stretchable bio-integrated electronics based on carbon nanotube and graphene. Materials 2018, 11, 1163. [CrossRef]

111. Sebaa, M.; Nguyen, T.Y.; Paul, R.K.; Mulchandani, A.; Liu, H. Graphene and carbon nanotube-graphene hybrid nanomaterials for human embryonic stem cell culture. Mater. Lett. 2013, 92, 122-125. [CrossRef]

112. Chen, N.; Luo, B.; Patil, A.C.; Wang, J.; Gammad, G.G.L.; Yi, Z.; Liu, X.; Yen, S.C.; Ramakrishna, S.; Thakor, N.V. Nanotunnels within Poly (3, 4-ethylenedioxythiophene)-Carbon nanotube composite for highly sensitive neural interfacing. ACS Nano 2020, 14, 8059-8073. [CrossRef] [PubMed]

113. Lee, S.; Eom, T.; Kim, M.K.; Yang, S.G.; Shim, B.S. Durable soft neural micro-electrode coating by an electrochemical synthesis of PEDOT:PSS/graphene oxide composites. Electrochim. Acta 2019, 313, 79-90. [CrossRef]

114. Jeong, D.W.; Kim, G.H.; Kim, N.Y.; Lee, Z.; Jung, S.D.; Lee, J.O. A high-performance transparent graphene/vertically aligned carbon nanotube (VACNT) hybrid electrode for neural interfacing. RSC Adv. 2017, 7, 3273-3281. [CrossRef]

115. Iijima, S. Helical microtubules of graphitic carbon. Nature 1991, 354, 56-58. [CrossRef]

116. Hirsch, A. Functionalization of single-walled carbon nanotubes. Angew. Chem. Int. Ed. 2002, 41, 1853-1859. [CrossRef]

117. Jan, E.; Hendricks, J.L.; Husaini, V.; Richardson-Burns, S.M.; Sereno, A.; Martin, D.C.; Kotov, N.A. Layered carbon nanotubepolyelectrolyte electrodes outperform traditional neural interface materials. Nano Lett. 2009, 9, 4012-4018. [CrossRef]

118. Ansaldo, A.; Castagnola, E.; Maggiolini, E.; Fadiga, L.; Ricci, D. Superior electrochemical performance of carbon nanotubes directly grown on sharp microelectrodes. ACS Nano 2011, 5, 2206-2214. [CrossRef]

119. Keefer, E.W.; Botterman, B.R.; Romero, M.I.; Rossi, A.F.; Gross, G.W. Carbon nanotube coating improves neuronal recordings. Nat. Nanotech. 2008, 3, 434-439. [CrossRef] 
120. Ben-Jacob, E.; Hanein, Y. Carbon nanotube micro-electrodes for neuronal interfacing. J. Mater. Chem. 2008, 18, 5181-5186. [CrossRef]

121. Kozai, T.D.Y.; Catt, K.; Du, Z.; Na, K.; Srivannavit, O.; Haque, R.M.; Seymour, J.; Wise, K.D.; Yoon, E.; Cui, X.T. Chronic In Vivo evaluation of PEDOT/CNT for stable neural recordings. IEEE Trans. Biomed. Eng. 2016, 63, 111-119. [CrossRef]

122. Liu, X.M.; Baronian, K.H.R.; Downard, A.J. Direct growth of vertically aligned carbon nanotubes on a planar carbon substrate by thermal chemical vapour deposition. Carbon 2009, 47, 500-506. [CrossRef]

123. Tahir, M.; He, L.; Haider, W.A.; Yang, W.; Hon, X.F.; Guo, Y.Q.; Pan, X.L.; Tang, H.; Li, Y.X.; Mai, L.Q. Co-electrodeposited porous PEDOT-CNT microelectrodes for integrated micro-supercapacitors with high energy density, high rate capability, and long cycling life. Nanoscale 2019, 11, 7761-7770. [CrossRef]

124. Kumar, M.; Ando, Y. Chemical vapor deposition of carbon nanotubes: A review on growth mechanism and mass production. J. Nanosci. Nanotechnol. 2010, 10, 3739-3758. [CrossRef]

125. Chen, C.M.; Dai, Y.M.; Huang, J.G.; Jehng, J.M. Intermetallic catalyst for carbon nanotubes (CNTs) growth by thermal chemical vapor deposition method. Carbon 2006, 44, 1808-1820. [CrossRef]

126. Lee, C.J.; Park, J.; Huh, Y.; Lee, J.Y. Temperature effect on the growth of carbon nanotubes using thermal chemical vapor deposition. Chem. Phys. Lett. 2001, 343, 33-38. [CrossRef]

127. Lee, C.J.; Park, J. Growth model of bamboo-shaped carbon nanotubes by thermal chemical vapor deposition. Appl. Phys. Lett. 2000, 77, 3397-3399. [CrossRef]

128. Wei, Y.Y.; Eres, G.; Merkulov, V.I.; Lowndes, D.H. Effect of catalyst film thickness on carbon nanotube growth by selective area chemical vapor deposition. Appl. Phys. Lett. 2001, 78, 1394-1396. [CrossRef]

129. Hannula, P.M.; Peltonen, A.; Aromaa, J.; Janas, D.; Lundström, M.; Wilson, B.P.; Koziol, K.; Forsén, O. Carbon nanotube-copper composites by electrodeposition on carbon nanotube fibers. Carbon 2016, 107, 281-287. [CrossRef]

130. Liu, Y.; Guo, N.; Yin, P.; Zhang, C. Facile growth of carbon nanotubes using microwave ovens: The emerging application of highly efficient domestic plasma reactors. Nanoscale Adv. 2019, 1, 4546-4559. [CrossRef]

131. Gheith, M.K.; Pappas, T.C.; Liopo, A.V.; Sinani, V.A.; Shim, B.S.; Motamedi, M.; Wicksted, J.P.; Kotov, N.A. Stimulation of neural cells by lateral currents in conductive layer-by-layer films of single-walled carbon nanotubes. Adv. Mater. 2006, 18, $2975-2979$. [CrossRef]

132. Saetia, K.; Schnorr, J.M.; Mannarino, M.M.; Kim, S.Y.; Rutledge, G.C.; Swager, T.M.; Hammond, P.T. Spray-layer-by-layer carbon nanotube/electrospun fiber electrodes for flexible chemiresistive sensor applications. Adv. Funct. Mater. 2014, $24,492-502$. [CrossRef]

133. Manjunatha, R.; Suresh, G.S.; Melo, J.S.; D’Souza, S.F.; Venkatesha, T.V. Simultaneous determination of ascorbic acid, dopamine and uric acid using polystyrene sulfonate wrapped multiwalled carbon nanotubes bound to graphite electrode through layer-bylayer technique. Sens. Actuators B Chem. 2010, 145, 643-650. [CrossRef]

134. Gabriel, G.; Gómez, R.; Bongard, M.; Benito, N.; Fernández, E.; Villa, R. Easily made single-walled carbon nanotube surface microelectrodes for neuronal applications. Biosens. Bioelectron. 2009, 24, 1942-1948. [CrossRef]

135. Nguyen-Vu, T.D.; Chen, H.; Cassell, A.M.; Andrews, R.; Meyyappan, M.; Li, J. Vertically aligned carbon nanofiber arrays: An advance toward electrical-neural interfaces. Small 2006, 2, 89-94. [CrossRef]

136. Gooding, J.J.; Chou, A.; Liu, J.; Losic, D.; Shapter, J.G.; Hibbert, D.B. The effects of the lengths and orientations of single-walled carbon nanotubes on the electrochemistry of nanotube-modified electrodes. Electrochem. Commun. 2007, 9, 1677-1683. [CrossRef]

137. Spira, M.E.; Hai, A. Multi-electrode array technologies for neuroscience and cardiology. Nat. Nanotechnol. 2013, 8, 83. [CrossRef] [PubMed]

138. Boccaccini, A.R.; Cho, J.; Roether, J.A.; Thomas, B.J.C.; Minay, E.J.; Shaffer, M.S.P. Electrophoretic deposition of carbon nanotubes. Carbon 2006, 44, 3149-3160. [CrossRef]

139. Ryman-Rasmussen, J.P.; Cesta, M.F.; Brody, A.R.; Shipley-Phillips, J.K.; Everitt, J.I.; Tewksbury, E.W.; Moss, O.R.; Wong, B.A.; Dodd, D.E.; Andersen, M.E.; et al. Inhaled carbon nanotubes reach the subpleural tissue in mice. Nat. Nanotechnol. 2009, 4, 747-751. [CrossRef]

140. Kolosnjaj-Tabi, J.; Hartman, K.B.; Boudjemaa, S.; Ananta, J.S.; Morgant, G.; Szwarc, H.; Wilson, L.J.; Moussa, F. In Vivo behavior of large doses of ultrashort and full-length single-walled carbon nanotubes after oral and intraperitoneal administration to Swiss mice. ACS Nano 2010, 4, 1481-1492. [CrossRef]

141. Cho, Y.; Borgens, R.B. The effect of an electrically conductive carbon nanotube/collagen composite on neurite outgrowth of PC12 cells. J. Biomed. Mater. Res. A 2010, 95, 510-517. [CrossRef] [PubMed]

142. Steel, E.M.; Azar, J.Y.; Sundararaghavan, H.G. Electrospun hyaluronic acid-carbon nanotube nanofibers for neural engineering. Materialia 2020, 9, 100581. [CrossRef]

143. Piret, G.; Hébert, C.; Mazellier, J.P.; Rousseau, L.; Scorsone, E.; Cottance, M.; Lissorgues, G.; Heuschkel, M.O.; Picaud, S.; Bergonzo, P.; et al. 3D-nanostructured boron-doped diamond for microelectrode array neural interfacing. Biomaterials 2015, 53, 173-183. [CrossRef]

144. Yen, S.J.; Hsu, W.L.; Chen, Y.C.; Su, H.C.; Chang, Y.C.; Chen, H.; Yeh, S.R.; Yew, T.R. The enhancement of neural growth by amino-functionalization on carbon nanotubes as a neural electrode. Biosens. Bioelectron. 2011, 26, 4124-4132. [CrossRef]

145. Luo, X.; Matranga, C.; Tan, S.; Alba, N.; Cui, X.T. Carbon nanotube nanoreservior for controlled release of anti-inflammatory dexamethasone. Biomaterials 2011, 32, 6316-6323. [CrossRef] 
146. Akhavan, O.; Ghaderi, E. Differentiation of human neural stem cells into neural networks on graphene nanogrids. J. Mater. Chem. B 2013, 1, 6291-6301. [CrossRef] [PubMed]

147. Tang, M.; Song, Q.; Li, N.; Jiang, Z.; Huang, R.; Cheng, G. Enhancement of electrical signaling in neural networks on graphene films. Biomaterials 2013, 34, 6402-6411. [CrossRef] [PubMed]

148. Li, N.; Zhang, X.; Song, Q.; Su, R.; Zhang, Q.; Kong, T.; Liu, L.; Jin, G.; Tang, M.; Cheng, G. The promotion of neurite sprouting and outgrowth of mouse hippocampal cells in culture by graphene substrates. Biomaterials 2011, 32, 9374-9382. [CrossRef] [PubMed]

149. Abdelkader, A.M.; Cooper, A.J.; Dryfe, R.A.W.; Kinloch, I.A. How to get between the sheets: A review of recent works on the electrochemical exfoliation of graphene materials from bulk graphite. Nanoscale 2015, 7, 6944-6956. [CrossRef] [PubMed]

150. Parvez, K.; Wu, Z.S.; Li, R.; Liu, X.; Graf, R.; Feng, X.; Mullen, K. Exfoliation of graphite into graphene in aqueous solutions of inorganic salts. J. Am. Chem. Soc. 2014, 136, 6083-6091. [CrossRef]

151. Hernandez, Y.; Nicolosi, V.; Lotya, M.; Blighe, F.M.; Sun, Z.; De, S.; McGovern, I.T.; Holland, B.; Byrne, M.; Gun'Ko, Y.K.; et al. High-yield production of graphene by liquid-phase exfoliation of graphite. Nat. Nanotechnol. 2008, 3, 563-568. [CrossRef]

152. Su, C.Y.; Lu, A.Y.; Xu, Y.; Chen, F.R.; Khlobystov, A.N.; Li, L.J. High-quality thin graphene films from fast electrochemical exfoliation. ACS Nano 2011, 5, 2332-2339. [CrossRef]

153. Yang, Y.; Hou, H.; Zou, G.; Shi, W.; Shuai, H.; Li, J.; Ji, X. Electrochemical exfoliation of graphene-like two-dimensional nanomaterials. Nanoscale 2019, 11, 16-33. [CrossRef]

154. Yu, P.; Lowe, S.E.; Simon, G.P.; Zhong, Y.L. Electrochemical exfoliation of graphite and production of functional graphene. Curr. Opin. Colloid Interface Sci. 2015, 20, 329-338. [CrossRef]

155. Yan, K.; Fu, L.; Peng, H.; Liu, Z. Designed CVD growth of graphene via process engineering. Acc. Chem. Res. 2013, 46, 2263-2274. [CrossRef]

156. Chen, X.; Zhang, L.; Chen, S. Large area CVD growth of graphene. Synth. Met. 2015, 210, 95-108. [CrossRef]

157. Sun, Z.; Yan, Z.; Yao, J.; Beitler, E.; Zhu, Y.; Tour, J.M. Growth of graphene from solid carbon sources. Nature 2010, 468, 549-552. [CrossRef] [PubMed]

158. Lu, Y.; Lyu, H.; Richardson, A.G.; Lucas, T.H.; Kuzum, D. Flexible neural electrode array based-on porous graphene for cortical microstimulation and sensing. Sci. Rep. 2016, 6, 33526. [CrossRef]

159. Kuzum, D.; Takano, H.; Shim, E.; Reed, J.C.; Juul, H.; Richardson, A.G.; de Vries, J.; Bink, H.; Dichter, M.A.; Lucas, T.H.; et al. Transparent and flexible low noise graphene electrodes for simultaneous electrophysiology and neuroimaging. Nat. Commun. 2014, 5, 5259. [CrossRef] [PubMed]

160. Heo, C.; Yoo, J.; Lee, S.; Jo, A.; Jung, S.; Yoo, H.; Lee, Y.H.; Suh, M. The control of neural cell-to-cell interactions through non-contact electrical field stimulation using graphene electrodes. Biomaterials 2011, 32, 19-27. [CrossRef]

161. Ryu, S.; Kim, B.S. Culture of neural cells and stem cells on graphene. Tissue Eng. Regen. Med. 2013, 10, 39-46. [CrossRef]

162. Serrano, M.C.; Feito, M.J.; González-Mayorga, A.; Diez-Orejas, R.; Matesanz, M.C.; Portolés, M.T. Response of macrophages and neural cells in contact with reduced graphene oxide microfibers. Biomater. Sci. 2018, 6, 2987-2997. [CrossRef]

163. Hong, S.W.; Lee, J.H.; Kang, S.H.; Hwang, E.Y.; Hwang, Y.S.; Lee, M.H.; Han, D.W.; Park, J.C. Enhanced neural cell adhesion and neurite outgrowth on graphene-based biomimetic substrates. Biomed. Res. Int. 2014, 2014, 212149. [CrossRef]

164. Solanki, A.; Chueng, S.T.D.; Yin, P.T.; Kappera, R.; Chhowalla, M.; Lee, K.B. Axonal alignment and enhanced neuronal differentiation of neural stem cells on graphene-nanoparticle hybrid structures. Adv. Mater. 2013, 25, 5477-5482. [CrossRef]

165. Zhang, S.; Yang, K.; Feng, L.; Liu, Z. In Vitro and In Vivo behaviors of dextran functionalized graphene. Carbon 2011, 49, 4040-4049. [CrossRef]

166. Taylor, I.M.; Robbins, E.M.; Catt, K.A.; Cody, P.A.; Happe, C.L.; Cui, X.T. Enhanced dopamine detection sensitivity by PEDOT/graphene oxide coating on In Vivo carbon fiber electrodes. Biosens. Bioelectron. 2017, 89, 400-410. [CrossRef]

167. Hwang, D.W.; Kim, H.Y.; Li, F.; Park, J.Y.; Kim, D.; Park, J.H.; Han, H.S.; Byun, J.W.; Lee, Y.S.; Jeong, J.M.; et al. In Vivo visualization of endogenous miR-21 using hyaluronic acid-coated graphene oxide for targeted cancer therapy. Biomaterials 2017, 121, 144-154. [CrossRef]

168. Bourrier, A.; Shkorbatova, P.; Bonizzato, M.; Rey, E.; Barraud, Q.; Courtine, G.; Othmen, R.; Reita, V.; Bouchiat, V.; Delacour, C. Monolayer graphene coating of intracortical probes for long-lasting neural activity monitoring. Adv. Healthc. Mater. 2019, 8, 1801331. [CrossRef] [PubMed]

169. Park, S.Y.; Park, J.; Sim, S.H.; Sung, M.G.; Kim, K.S.; Hong, B.H.; Hong, S. Enhanced differentiation of human neural stem cells into neurons on graphene. Adv. Mater. 2011, 23, H263-H267. [CrossRef]

170. Green, R.; Abidian, M.R. Conducting polymers for neural prosthetic and neural interface applications. Adv. Mater. 2015, 27, 7620-7637. [CrossRef]

171. Green, R.A.; Lovell, N.H.; Wallace, G.G.; Poole-Warren, L.A. Conducting polymers for neural interfaces: Challenges in developing an effective long-term implant. Biomaterials 2008, 29, 3393-3399. [CrossRef] [PubMed]

172. Fincher, C.R., Jr.; Ozaki, M.; Heeger, A.J.; MacDiarmid, A.G. Donor and acceptor states in lightly doped polyacetylene, $(\mathrm{CH})_{\mathrm{x}}$. Phys. Rev. B 1979, 19, 4140. [CrossRef]

173. Heeger, A.J. Semiconducting polymers: The third generation. Chem. Soc. Rev. 2010, 39, 2354-2371. [CrossRef]

174. Shirakawa, H. The discovery of polyacetylene film: The dawning of an era of conducting polymers. Synth. Met. 2001, 40, 2574-2580. [CrossRef]

175. MacDiarmid, A.G. “Synthetic metals": A novel role for organic polymers. Synth. Met. 2001, 40, 2581-2590. 
176. Roncali, J. Conjugated poly(thiophenes): Synthesis, functionalization, and applications. Chem. Rev. 1992, 92, 711-738. [CrossRef]

177. Song, J.; Ma, G.; Qin, F.; Hu, L.; Luo, B.; Liu, T.; Yin, X.; Su, Z.; Zeng, Z.; Jiang, Y.; et al. High-conductivity, flexible and transparent PEDOT:PSS electrodes for high performance semi-transparent supercapacitors. Polymers 2020, 12, 450. [CrossRef]

178. Meng, Q.; Cai, K.; Chen, Y.; Chen, L. Research progress on conducting polymer based supercapacitor electrode materials. Nano Energy 2017, 36, 268-285. [CrossRef]

179. Luo, X.; Killard, A.J.; Morrin, A.; Smyth, M.R. Enhancement of a conducting polymer-based biosensor using carbon nanotubedoped polyaniline. Anal. Chim. Acta 2006, 575, 39-44. [CrossRef]

180. German, N.; Ramanaviciene, A.; Ramanavicius, A. Formation and electrochemical evaluation of polyaniline and polypyrrole nanocomposites based on glucose oxidase and gold nanostructures. Polymers 2020, 12, 3026. [CrossRef] [PubMed]

181. Mawad, D.; Stewart, E.; Officer, D.L.; Romeo, T.; Wagner, P.; Wagner, K.; Wallace, G.G. A single component conducting polymer hydrogel as a scaffold for tissue engineering. Adv. Funct. Mater. 2012, 22, 2692-2699. [CrossRef]

182. Tomczykowa, M.; Plonska-Brzezinska, M.E. Conducting polymers, hydrogels and their composites: Preparation, properties and bioapplications. Polymers 2019, 11, 350. [CrossRef]

183. Llorens, E.; Armelin, E.; Perez-Madrigal, M.D.M.; Valle, L.J.D.; Aleman, C.; Puiggali, J. Nanomembranes and nanofibers from biodegradable conducting polymers. Polymers 2013, 5, 1115-1157. [CrossRef]

184. Liu, Y.; Yin, P.; Chen, J.; Cui, B.; Zhang, C.; Wu, F. Conducting polymer-based composite materials for therapeutic implantations: From advanced drug delivery system to minimally invasive electronics. Int. J. Polym. Sci. 2020, 2020, 5659682. [CrossRef]

185. Kim, S.Y.; Kim, K.M.; Hoffman-Kim, D.; Song, H.K.; Palmore, G.T.R. Quantitative control of neuron adhesion at a neural interface using a conducting polymer composite with low electrical impedance. ACS Appl. Mater. Interfaces 2011, 3, 16-21. [CrossRef]

186. Wilks, S.J.; Richardson-Burns, S.M.; Hendricks, J.L.; Martin, D.C.; Otto, K.J. Poly (3,4-ethylene dioxythiophene) (PEDOT) as a micro-neural interface material for electrostimulation. Front. Neuroeng. 2009, 2, 7. [CrossRef] [PubMed]

187. Richardson-Burns, S.M.; Hendricks, J.L.; Foster, B.; Povlich, L.K.; Kim, D.H.; Martin, D.C. Polymerization of the conducting polymer poly(3,4-ethylenedioxythiophene) (PEDOT) around living neural cells. Biomaterials 2007, 28, 1539-1552. [CrossRef] [PubMed]

188. Abidian, M.R.; Ludwig, K.A.; Marzullo, T.C.; Martin, D.C.; Kipke, D.R. Interfacing conducting polymer nanotubes with the central nervous system: Chronic neural recording using poly (3,4-ethylenedioxythiophene) nanotubes. Adv. Mater. 2009, 21, 3764-3770. [CrossRef] [PubMed]

189. Cullen, D.K.; Patel, A.R.; Doorish, J.F.; Smith, D.H.; Pfister, B.J. Developing a tissue-engineered neural-electrical relay using encapsulated neuronal constructs on conducting polymer fibers. J. Neural Eng. 2008, 5, 374. [CrossRef]

190. Rossetti, N.; Hagler, J.E.; Kateb, P.; Cicoira, F. Neural and electromyography PEDOT electrodes for invasive stimulation and recording. J. Mater. Chem. C 2021, 9, 7243-7263. [CrossRef]

191. Li, C.; Bai, H.; Shi, G.Q. Conducting polymer nanomaterials: Electrosynthesis and applications. Chem. Soc. Rev. 2009, 38, 2397-2409. [CrossRef]

192. Venkatraman, S.; Hendricks, J.; King, Z.A.; Sereno, A.J.; Richardson-Burns, S.; Martin, D.C.; Carmena, J.M. In Vitro and In Vivo evaluation of PEDOT microelectrodes for neural stimulation and recording. IEEE Trans. Neural Syst. Rehabil. Eng. 2011, 19, 307-316. [CrossRef]

193. Castagnola, V.; Descamps, E.; Lecestre, A.; Dahan, L.; Remaud, J.; Nowak, L.G.; Bergaud, C. Parylene-based flexible neural probes with PEDOT coated surface for brain stimulation and recording. Biosens. Bioelectron. 2015, 67, 450-457. [CrossRef]

194. Baek, S.; Green, R.A.; Poole-Warren, L.A. Effects of dopants on the biomechanical properties of conducting polymer films on platinum electrodes. J. Biomed. Mater. Res. A 2014, 102, 2743-2754. [CrossRef]

195. Baek, S.; Green, R.A.; Poole-Warren, L.A. The biological and electrical trade-offs related to the thickness of conducting polymers for neural applications. Acta Biomater. 2014, 10, 3048-3058. [CrossRef]

196. Ludwig, K.A.; Uram, J.D.; Yang, J.; Martin, D.C.; Kipke, D.R. Chronic neural recordings using silicon microelectrode arrays electrochemically deposited with a poly (3,4-ethylenedioxythiophene) (PEDOT) film. J. Neural Eng. 2006, 3, 59. [CrossRef] [PubMed]

197. Lundin, V.; Herland, A.; Berggren, M.; Jager, E.W.H.; Teixeira, A.I. Control of neural stem cell survival by electroactive polymer substrates. PLoS ONE 2011, 6, e18624. [CrossRef]

198. Park, K.H.; Jo, E.A.; Na, K. Heparin/polypyrrole (PPy) composite on gold-coated matrix for the neurite outgrowth of PC12 cells by electrical stimulation. Biotechnol. Bioprocess Eng. 2007, 12, 463. [CrossRef]

199. Green, R.A.; Lovell, N.H.; Poole-Warren, L.A. Cell attachment functionality of bioactive conducting polymers for neural interfaces. Biomaterials 2009, 30, 3637-3644. [CrossRef]

200. Cui, X.; Wiler, J.; Dzaman, M.; Altschuler, R.A.; Martin, D.C. In Vivo studies of polypyrrole/peptide coated neural probes. Biomaterials 2003, 24, 777-787. [CrossRef]

201. Evans, A.J.; Thompson, B.C.; Wallace, G.G.; Millard, R.; O’Leary, S.J.; Clark, G.M.; Shepherd, R.K.; Richardson, R.T. Promoting neurite outgrowth from spiral ganglion neuron explants using polypyrrole/BDNF-coated electrodes. J. Biomed. Mater. Res. A 2009, 91A, 241-250. [CrossRef]

202. Gomez, N.; Schmidt, C.E. Nerve growth factor-immobilized polypyrrole: Bioactive electrically conducting polymer for enhanced neurite extension. J. Biomed. Mater. Res. A 2007, 81, 135-149. [CrossRef] 
203. Kim, S.; Jang, L.K.; Jang, M.; Lee, S.; Hardy, J.G.; Lee, J.Y. Electrically conductive polydopamine-polypyrrole as high performance biomaterials for cell stimulation In Vitro and electrical signal recording In Vivo. ACS Appl. Mater. Interfaces 2018, 10, 33032-33042. [CrossRef] [PubMed]

204. Wadhwa, R.; Lagenaur, C.F.; Cui, X.T. Electrochemically controlled release of dexamethasone from conducting polymer polypyrrole coated electrode. J. Control. Release 2006, 110, 531-541. [CrossRef]

205. Yang, J.; Martin, D.C. Microporous conducting polymers on neural microelectrode arrays: I Electrochemical deposition. Sens. Actuators B Chem. 2004, 101, 133-142. [CrossRef]

206. Abidian, M.R.; Martin, D.C. Experimental and theoretical characterization of implantable neural microelectrodes modified with conducting polymer nanotubes. Biomaterials 2008, 29, 1273-1283. [CrossRef]

207. Luo, X.; Weaver, C.L.; Zhou, D.D.; Greenberg, R.; Cui, X.T. Highly stable carbon nanotube doped poly (3, 4-ethylenedioxythiophene) for chronic neural stimulation. Biomaterials 2011, 32, 5551-5557. [CrossRef]

208. Tian, H.C.; Liu, J.Q.; Wei, D.X.; Kang, X.Y.; Zhang, C.; Du, J.C.; Yang, B.; Chen, X.; Zhu, H.Y.; Li, Y.N.; et al. Graphene oxide doped conducting polymer nanocomposite film for electrode-tissue interface. Biomaterials 2014, 35, 2120-2129. [CrossRef] [PubMed]

209. Boehler, C.; Oberueber, F.; Schlabach, S.; Stieglitz, T.; Asplund, M. Long-term stable adhesion for conducting polymers in biomedical applications: IrOx and nanostructured platinum solve the chronic challenge. ACS Appl. Mater. Interfaces 2017, 9 , 189-197. [CrossRef]

210. Kim, R.; Nam, Y. Polydopamine-doped conductive polymer microelectrodes for neural recording and stimulation. J. Neurosci. Methods 2019, 326, 108369. [CrossRef]

211. Rao, L.; Zhou, H.; Li, T.; Li, C.; Duan, Y.Y. Polyethylene glycol-containing polyurethane hydrogel coatings for improving the biocompatibility of neural electrodes. Acta Biomater. 2012, 8, 2233-2242. [CrossRef] [PubMed]

212. Dalrymple, A.N.; Robles, U.A.; Huynh, M.; Nayagam, B.A.; Green, R.A.; Poole-Warren, L.A.; Fallon, J.B.; Shepherd, R.K. Electrochemical and biological performance of chronically stimulated conductive hydrogel electrodes. J. Neural Eng. 2020, 17, 026018. [CrossRef]

213. Lu, Y.; Wang, D.; Li, T.; Zhao, X.; Cao, Y.; Yang, H.; Duan, Y.Y. Poly (vinyl alcohol)/poly (acrylic acid) hydrogel coatings for improving electrode-neural tissue interface. Biomaterials 2009, 30, 4143-4151. [CrossRef]

214. Kim, D.H.; Wiler, J.A.; Anderson, D.J.; Kipke, D.R.; Martin, D.C. Conducting polymers on hydrogel-coated neural electrode provide sensitive neural recordings in auditory cortex. Acta Biomater. 2010, 6, 57-62. [CrossRef]

215. Hassarati, R.T.; Dueck, W.F.; Tasche, C.; Carter, P.M.; Poole-Warren, L.A.; Green, R.A. Improving cochlear implant properties through conductive hydrogel coatings. IEEE Trans. Neural Syst. Rehabil. Eng. 2014, 22, 411-418. [CrossRef]

216. He, L.; Lin, D.; Wang, Y.; Xiao, Y.; Che, J. Electroactive SWNT/PEGDA hybrid hydrogel coating for bio-electrode interface. Colloids Surf. B Biointerfaces 2011, 87, 273-279. [CrossRef]

217. Kleber, C.; Bruns, M.; Lienkamp, K.; Rühe, J.; Asplund, M. An interpenetrating, microstructurable and covalently attached conducting polymer hydrogel for neural interfaces. Acta Biomater. 2017, 58, 365-375. [CrossRef]

218. Green, R.A.; Lim, K.S.; Henderson, W.C.; Hassarati, R.T.; Martens, P.J.; Lovell, N.H.; Poole-Warren, L.A. Living electrodes: Tissue engineering the neural interface. In Proceedings of the 35th Annual International Conference of the IEEE Engineering in Medicine and Biology Society (EMBC), Osaka, Japan, 3-7 July 2013; pp. 6957-6960.

219. Aregueta-Robles, U.A.; Lim, K.S.; Martens, P.J.; Lovell, N.H.; Poole-Warren, L.A.; Green, R. Producing 3D neuronal networks in hydrogels for living bionic device interfaces. In Proceedings of the 37th Annual International Conference of the IEEE Engineering in Medicine and Biology Society (EMBC), Milan, Italy, 25-29 August 2015; pp. 2600-2603.

220. Goding, J.A.; Gilmour, A.D.; Aregueta-Robles, U.A.; Hasan, E.A.; Green, R.A. Living bioelectronics: Strategies for developing an effective long-term implant with functional neural connections. Adv. Funct. Mater. 2018, 28, 1702969. [CrossRef]

221. Pan, L.; Yu, G.; Zhai, D.; Lee, H.R.; Zhao, W.; Liu, N.; Wang, H.; Tee, B.C.-K.; Shi, Y.; Cui, Y.; et al. Hierarchical nanostructured conducting polymer hydrogel with high electrochemical activity. Proc. Natl. Acad. Sci. USA 2012, 109, 9287-9292. [CrossRef] [PubMed]

222. Rinoldi, C.; Lanzi, M.; Fiorelli, R.; Nakielski, P.; Zembrzycki, K.; Kowalewski, T.; Urbanek, O.; Grippo, V.; Jezierska-Woźniak, K.; Maksymowicz, W.; et al. Three-dimensional printable conductive semi-interpenetrating polymer network hydrogel for neural tissue applications. Biomacromolecules 2021, 22, 3084-3098. [CrossRef]

223. Wu, X.; Liu, S.; Chen, K.; Wang, F.; Feng, C.; Xu, L.; Zhang, D. 3D printed chitosan-gelatine hydrogel coating on titanium alloy surface as biological fixation interface of artificial joint prosthesis. Int. J. Biol. Macromol. 2021, 182, 669-679. [CrossRef]

224. Jiang, J.P.; Liu, X.Y.; Zhao, F.; Zhu, X.; Li, X.Y.; Niu, X.G.; Yao, Z.T.; Dai, C.; Xu, H.Y.; Ma, K.; et al. Three-dimensional bioprinting collagen/silk fibroin scaffold combined with neural stem cells promotes nerve regeneration after spinal cord injury. Neural Regen Res. 2020, 15, 959-968.

225. Kuzmenko, V.; Karabulut, E.; Pernevik, E.; Enoksson, P.; Gatenholm, P. Tailor-made conductive inks from cellulose nanofibrils for 3D printing of neural guidelines. Carbohydr. Polym. 2018, 189, 22-30. [CrossRef]

226. Golabchi, A.; Wu, B.; Cao, B.; Bettinger, C.J.; Cui, X.T. Zwitterionic polymer/polydopamine coating reduce acute inflammatory tissue responses to neural implants. Biomaterials 2019, 225, 119519. [CrossRef] 